by P. C. Bandopadhyay ${ }^{1}$, Biswajit Ghosh ${ }^{2}$ and Mara Limonta ${ }^{3}$

\title{
A reappraisal of the eruptive history and recent (1991-2009) volcanic eruptions of the Barren Island, Andaman Sea
}

\author{
${ }^{1}$ Department of Geology, University of Calcutta. Formerly with the Geological Survey of India, 40, Bajeshibpur Road, Howrah - 711 102, West \\ Bengal, India. E-mail: hiyabando@yahoo.co.uk \\ ${ }^{2}$ Department of Geology, University of Calcutta, 35 Ballygunge Circular Road, Kolkata - 700019. E-mail: bghosh_geol@hotmail.com \\ ${ }^{3}$ Department of Earth and Environmental Sciences, Università di Milano-Bicocca, 20126 Milano, Italy. E-mail: m.limontal @ campus.unimib.it
}

The Barren Island volcano in the Western Sunda Arc has displayed explosive Strombolian eruptions for more than two decades. This recent explosive event, together with the historic and prehistoric volcanic landforms, present reliable information about explosive Strombolian eruptions and the volcanological evolution of the Barren Island volcano. This study is a re-evaluation of existing knowledge and incorporates new information and interpretations of the recent and past volcanic activity on Barren Island. Direct observations of explosive eruptions since 1991 showed discrete events of bursting and ballistic transport of blocks and formation of sustained ash plumes, indicating Strombolian and violent Strombolian eruptions. Active lava flows were not seen during the observations which, instead, reveal intact preservation of the historic lava flows. A prehistoric mafic stratocone with a central depression (caldera), a central scoria cone with summit crater and abundant basaltic lava flows of historic eruptions and the scoria cones of the recent activity are the major volcanic landforms. They bear evidence of alternating effusive and explosive activity during prehistoric times accompanied by caldera forming activity; scoria cone Strombolian activity switches over to effusive events during the historic period and exclusively Strombolian activity during recent times. The results of this study differ from previous studies that interpreted several episodes of active lava flows and Hawaiian, Plinian and Vulcanian styles of the recent eruptions. It also provides new insights into the volcanological evolution of the Barren Island volcano which is crucial in understanding the future behaviour of the volcano and risk assessment.

\section{Introduction}

The active volcanic centre of Barren Island $\left(12^{\circ} 15^{\prime} \mathrm{N}\right.$ and $93^{\circ} 51^{\prime}$ E) in the Andaman Sea, herein referred to as Barren volcano, is located $135 \mathrm{~km}$ northeast of Port Blair, Andaman Islands, India (Fig. 1). Narcondam, a dormant volcano lies $140 \mathrm{~km}$ north of the Barren Island. Both of them lie on the chain of active volcanoes of Java and Sumatra and extinct volcanoes of Myanmar, known as Neogene inner arc volcanic belt of Southeast Asia (Fig. 1). It is believed that the Barren volcano erupted first in prehistoric time (late Pleistocene; Shankar et al., 2001). Recently, a minimum age of $1.8 \mathrm{Ma}$ for the active Barren Island volcano has been suggested based on ${ }^{40} \mathrm{Ar}-{ }^{39} \mathrm{Ar}$ dating of ash layers sampled in a sediment core drilled $32 \mathrm{~km}$ southeast of Barren Island (Ray et al., 2013)._Hobday and Mallet (1885), in a pioneering study, thoroughly examined the geology of Barren Island, established its volcanic nature and origin, described field attributes and lithology, and prepared a topographic and geologic map of the island (Fig. 2), and discussed the prehistoric and historic eruptions. They mentioned several episodes of eruptions during historic (1787-1832) periods and provided a detailed chronology of these eruptions. Their study is still crucial in understanding the incidence of active lava flows during recent volcanic activity.

The volcano has been active intermittently since 1991 . The recent eruptions, eruptive products, and the petrology of the fragmental ejecta in Barren Island have been studied and interpreted (Haldar et al., 1992, 1999; Shankar et al., 2001; Haldar and Luhr, 2003; Alam et al., 2004; Bandopadhyay, et al., 2006; Luhr and Haldar, 2006; Pal et al., 2007, 2010; Chandrasekharam et al., 2009; Sheth et al., 2009, 2010, 2011). Awasthi et al. (2010) undertook $C^{14}$ dating of ash layers sampled from a marine sediment core taken from a location, $32 \mathrm{~km}$ southeast of Barren Island and interpreted the history of the last 72,000 $\mathrm{yr}$ of eruptions on Barren Island. However, previous studies have focused on petrology of the ejected material and inferred active lava flows with limited discussion on the nature and style of the recent eruptions and the volcanic landforms. Sheth et al. (2009) studied several stratocone sections exposed on Barren Island and made detailed documentation of the field attributes of the prehistoric stratocone volcano including delineation of pyroclastic surge and flow deposits. Sheth et al. (2011) also provided a spectacular example of toothpaste lava flows, described their physical and chemical attributes and suggested that these possibly formed during the 1994-95 eruptions. 


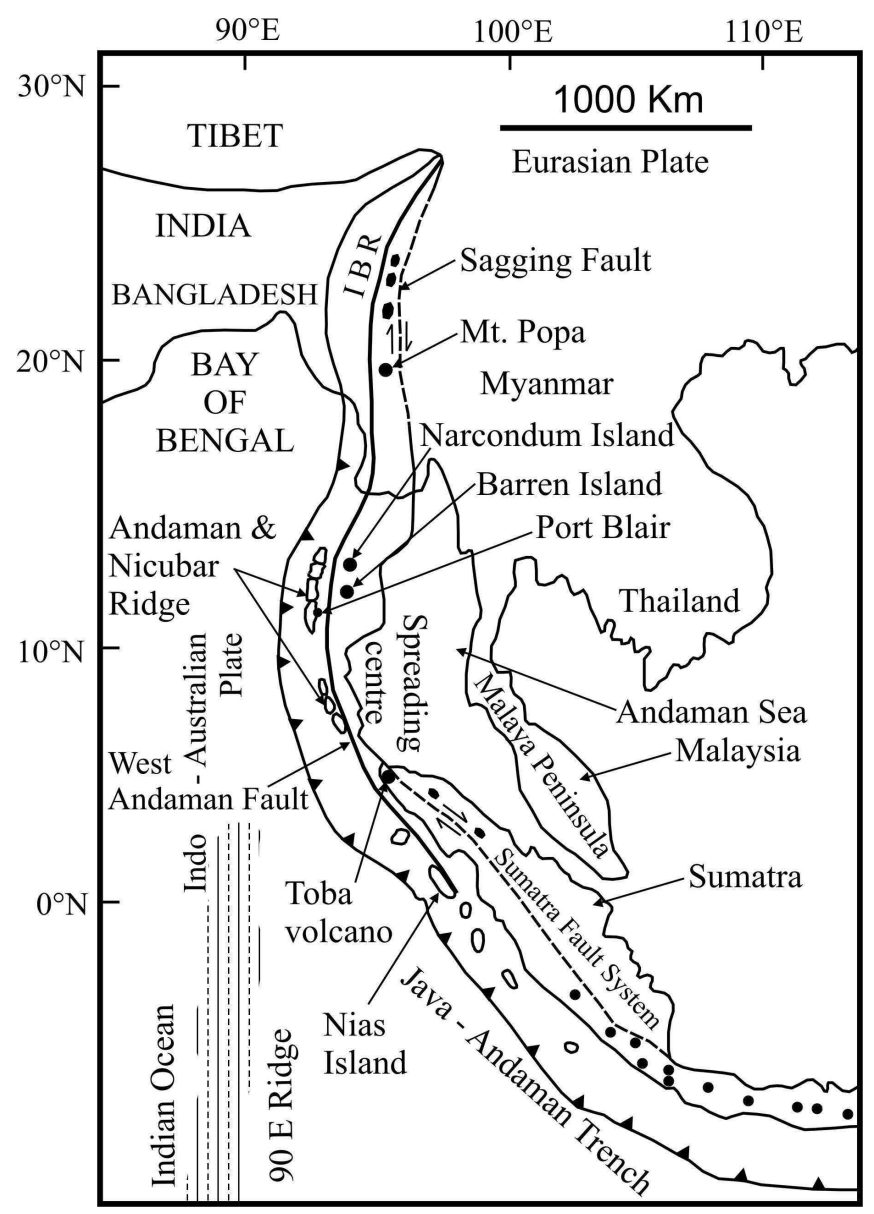

Figure 1. Geodynamic framework of Western Sunda Arc, Northeast Indian Ocean, modified after Curray (2005) showing position of Barren and Narcondam volcanic Islands within the active and Quaternary Myanmar-Sumatra inner arc volcanic belt (solid black circles)

Shankar et al., (2001) however, suggested that the toothpaste aa flows (which they described as ropy pahoehoe) as part of the historic (17891832) eruptions. Previous studies claimed that voluminous outpouring of lavas occurred during eruptions in 1991, 1994-95, 2005-06 and 2008-09 (Haldar et al., 1992; Shankar et al., 2001; Haldar and Luhr, 2003; Chandrasekharam et al., 2009; Sheth, et al., 2009, 2010) and considered that the recent activity started as Strombolian and subsequently changed to Hawaiian, Vulcanian and Plinian types of eruptions (Shankar et al., 2001; Haldar and Luhr, 2003; Sheth et al., 2009). However, the present authors feel that the methodology generally used to document the active lava flows (Landi et al., 2006; Calvari et al., 2005, 2006; Lombardo et al., 2004; Lodato et al., 2007) needs to be applied, and insufficient evidences of active lava flows coupled with ubiquitous and conspicuous presence of historic lava flows until 2005 makes the claim unconvincing.

The juvenile lava clasts in several studies have been identified as the product of 1991, 1994-95 or of 2005-06 eruptions (Haldar et al., 1992; Haldar and Luhr, 2003, Chandrasekharam et al., 2009; Pal et al., 2010). In fact, re-ejected material and juvenile clasts in successive eruptive phases are mixed together during and after each eruption. Therefore, collected samples of lava clasts may not be unequivocally attributed to a particular eruptive event such as those of 1991, 199495, 2005 and 2006. Furthermore, sampling of lava clasts in most cases was not done during the time of eruptive activity. Even, fragmental ejecta collected during an eruption by the first author may not necessarily be ascribed to a particular eruptive event simply because they were hot. Therefore, the nature and style of the recent eruptions, nature of eruptive products, volcanic landforms and the incidence of lava flow events during recent eruptions are contentious issues.

This detailed review evaluates existing knowledge of the physical volcanology of Barren Island and presents an eye witness account of the recent eruptions. Reconstruction of historic and prehistoric eruptions based on examination of deposits and landforms has also been attempted. This paper also addresses debatable issues such as the occurrence of lava flows during the recent eruptions and styles and dynamics of recent eruptions which during the last two decades have scientifically been observed on several occasions from ships and from ground close to the eruption site. The recent volcanic activity, which continued for two decades, provided a unique opportunity to learn about long-duration Strombolian eruptions and thus improve our understanding of this type of explosive activity. Data for this study were collected from a) day time and night time shipboard observations of the eruptions from several viewpoints in the months of May, July, August 1991, January 1994 and 2006, b) ground observations in May, 2005, March 2006 and in January, 2009, c) field examination of erupted products and volcanic landforms, d) analysis of information obtained from websites, local newspapers, photographs, and Coastguard personnel at Port Blair, e) analysis of video recordings of the 1991 and 2005 eruptions, f) comparison of the nature and style of the current eruptions with specific volcanoes where certain types of activity are common and, g) petrographic study of the uncontaminated ash of the 2005-2006 eruption.

\section{The Barren Island}

\section{Tectonic setting}

The Barren and the Narcondam volcanic islands in the Andaman Sea are part of the inner arc volcanic chain of the Western Sunda Arc defining a zone of underthrusting of the Indo-Australian Plate below the Southeast Asian plate, leading the formation of a major island arc-trench system (Fig. 1). The oblique motion of the convergence with variable speed and direction in different parts of the arc system and the inhomogeneous distribution of the movement vectors in different parts of the arc have caused strike-slip faulting parallel to the trench (West Andaman Fault, Sumatra Fault System and Sagging Fault in Myanmar in Fig. 1), generation of a plate sliver called the Burma microplate, transtension and formation of a back arc, pullapart extensional basin (Andaman Sea) with active sea floor spreading forming during the last 4-5 Ma (Raju, 2005; Curray, 2005). The Burma microplate includes the currently erupting Barren Island and, to the west, the islands of Andaman-Nicobar Ridge that expose deep sea turbidites formed in a submarine fan, dismembered ophiolites and sedimentary mélanges of a subduction-accretion complex (Bandopadhyay, 2005, 2012).

\section{Physiography}

The subaerial Barren Island volcano rises from a depth of 2000$2250 \mathrm{mbsl}$ to an elevation of $\sim 354$ masl. It is underlain by 8 to $10 \mathrm{~km}$ thick oceanic crust. The island has a diameter of $\sim 3 \mathrm{~km}$ covering an 


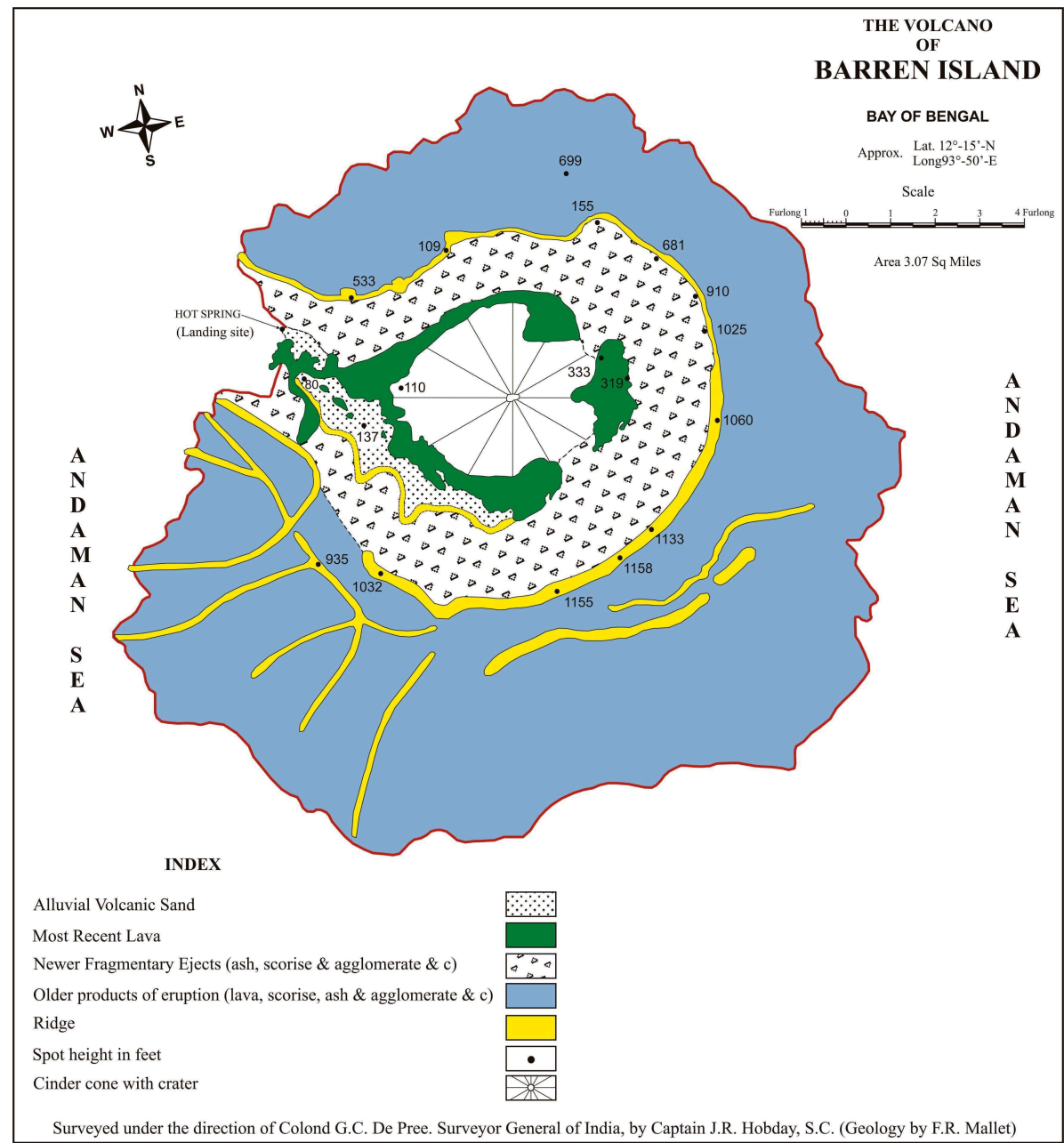

Figure 2. Topographic cum geologic map of the Barren Island reproduced from Hobday and Mallet (1885). Historic lava flows almost encircle the scoria cone and lava stream flowed down the western slope, crossed the breached wall and poured into the sea. The formation of terminal lava lobe (where the lava stream meets the sea) is clear in the map. This protrusion of historic lava into the sea has in a monthly summary of Barren activity http://02/2003(BGVN 28: 02) been erroneously depicted as a lava flow delta of 1994-95 eruption (Fig. 7).

Schmincke, 2004; Landi et al., 2006; Patrick et al., 2007; Valentine and Gregg, 2008). The recent activity was first observed on 28 March 1991. Subsequently the volcano has erupted several times until recently (Sheth et al., 2010). A local newspaper has reported eruptions on Barren Island during February 2014.

An oblique photograph of the eruption in early May 1991 shows an eruption from a subsidiary vent located below the summit crater with emission of loosely convoluted ash plumes and drifting of the ash cloud due to a northerly blowing wind (Fig. 4b). The explosive eruption intensified within a fortnight and became more violent during July and August (Bandopadhyay, P.C. 1991 cited in Haldar et al., 1992). The flank vent merged with the summit crater and the eruption continued with explosive ejection of huge quantities of ash-rich magmatic gas that imparted a dark grey to black appearance to the eruption plume (Fig. 4c). Formation of an eruption column rising up to several hundreds of metres above the crater was also observed during the eruption. This is closely comparable to the paroxysmal event recorded during the $5^{\text {th }}$ April 2003 eruption at Stromboli volcano (Calvari et al., 2006). Sheth et al., (2009) described the event as sub-Plinian despite recording a peak (climactic) eruption column height of only $1 \mathrm{~km}$. After a continuous eruption of ash-laden gas, lapilli and blocks, the main eruptive phase waned towards the end of October 1991 and changed to intermittent ejection of ballistic material at intervals of five to ten minutes accompanied by spewing of thin smoke from the crater. Haldar et al. $(1992,1999)$ reported fumarolic

area of nearly $9 \mathrm{sq} \mathrm{kms.} \mathrm{A} \mathrm{nearly} \mathrm{circular} \mathrm{ridge} \mathrm{with} \mathrm{a} \mathrm{central}$ depression (amphitheatre), $1.6 \mathrm{~km}$ across encloses a scoria cone at its centre that has been the source of eruptions since 1787 (Hobday and Mallet, 1885) (Fig. 2). The area between the ridge and the scoria cone is a valley (an annular moat) that encircles the scoria cone. The gently sloping $\left(<25^{\circ}\right)$ outer walls of the ridge (island) are densely wooded. The circular ridge is much lower in the north than the south (Fig. 2). On the western side, there is a deep breach with a horse-shoe shaped opening (Fig. 2). The opening contains sandy ground floored with black alluvial sand and is the principal access for small boats (Fig. 3).

\section{Recent Eruptive History (1991-2009)}

The most obvious features on Barren Island that existed prior to the recent eruptions comprise a historic scoria cone with a small summit crater and related basaltic lava flows (Fig. 4a). Throughout the recent eruptive history, the volcanic activity predominantly comprised Strombolian or Strombolian-like eruptions from the scoria cone (Macdonald, 1972; Fisher and Schmincke, 1984; Parfitt, 2004; activity during the end of the eruptive phase. The crater diameter was enlarged and its height was reduced due to collapse of the inner crater wall, resulting in formation of a bowl-shaped structure (Fig. 4c). Shankar et al. (2001) reported that the floor of the crater was filled with debris that were possibly recycled during the subsequent episodes of the eruption. The volcano erupted again in 1994-95 but the activity was less intense than in 1991 (Haldar et al., 1999). The activity comprised emission of gas and ash with minor amounts of ballistic clasts from the summit crater.

The volcano started erupting again on $28^{\text {th }}$ May 2005. Emission of light grey gas and ash and forceful ejection of superheated white steam from the valley region lasted for a week (Bandopadhyay et al., 2006). On 13 June 2005 ground observations including video recordings of the eruption for about four hours were carried out close to the eruption (Fig. 5a). Voluminous and explosive ejections of gas, ash and ballistic clasts characterized this eruption. However no outpouring of coherent and molten rock material (lava flows) was observed during the paroxysmal event. Multiple eruption columns were observed, signifying several vents in simultaneous activity (Fig. 5b). The violent Strombolian explosions at Paricutin (Luhr and 


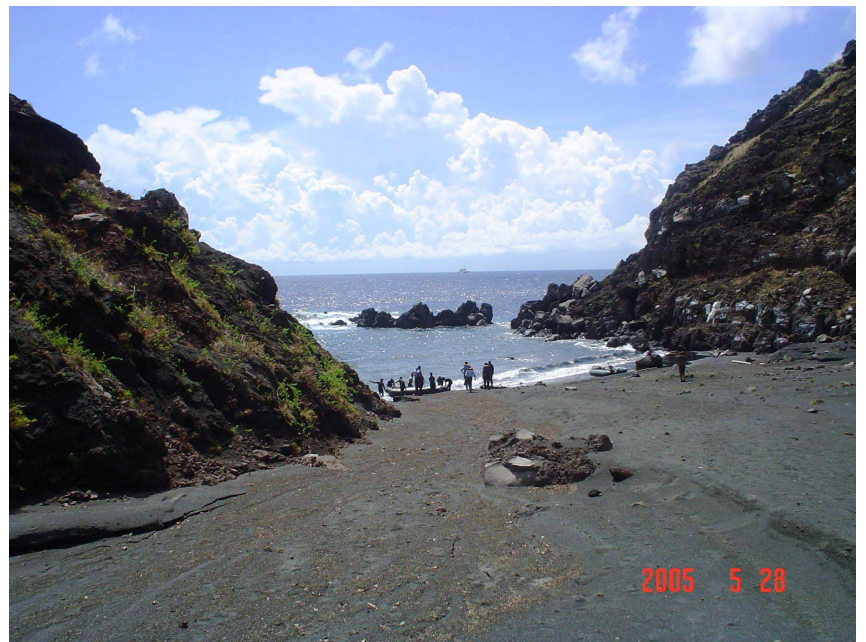

Figure 3. Breach on the western wall of the stratocone providing an opening for entering into the island and exposing prehistoric stratified volcanic rocks (shown in detail in Figure 8a). Note the small sandy beach where a boat ( 4 metres long) touches the shore. A narrow stretch floored with black alluvial sand in the foreground provides the route for reaching close to the historic cone/eruption site. Width of the beach is $20 \mathrm{~m}$.

Simkin, 1993) and Cerro Negro (Hill et al., 1998) also demonstrated multiple eruption column events. The almost continuous ejection of gas and ash, accompanied by discrete bursting of reddish blocks, at intervals of a few seconds, and transient flames during tall plume episodes were frequently observed during the night (Fig.5c, d). There was no sustained jetting of liquid lava characteristic of Hawaiian eruptions (Macdonald, 1972; Fisher and Schmincke, 1984; Parfitt, 2004). Forceful ejection of tephra-free white steam forming strong plumes, not accompanied by lava flows, were observed during July 2005 at the landing site (Fig 5e). The westerly sloping sandy ground (Fig. 3) is the main water course of the highly precipitous volcanic island which experiences its maximum rainfall between June and August every year. It is most likely that the surface run-off seeping down through the porous and fractured volcanic rocks, reached a depth where it was heated due to presence of a magma chamber in close proximity. The geothermally heated water turned into steam, rose back through deep cracks and formed strong steam plumes comparable to hot spring or geyser activity often associated with volcanoes (Macdonald, 1972; Schmincke, 2004). The landing site was marked as a site of hot spring activity in the descriptions made by Hobday and Mallet (1885). A comparison of photographs (Figs. $4 \mathrm{c}$ and $5 \mathrm{~d}$ ) shows that the low crater seen at the end of 1991 eruption had become a lofty conical hill around the central vent with a circular summit crater, recording the growth of the central cone with time. It was also observed that the conical historic cinder cone and the associated lava field remained intact (Fig. 5d), presumably because of northerly blowing winds during the eruption. This caused drifting and deposition of ash mainly over the northern flank and beyond the area of the scoria cone. Reddish ballistic clasts accumulated on the southern flank of the scoria cone as a dull blackish red apron (Fig. 5a, d). An on-ship observation on $13^{\text {th }}$ January 2006 described a Strombolian eruption characterized by discrete bursts occurring at intervals of a few to several seconds with emission of ballistics and dark smoke from the summit crater. On 12 March 2006 the eruption was a near continuous emission of ash and gas with intermittent
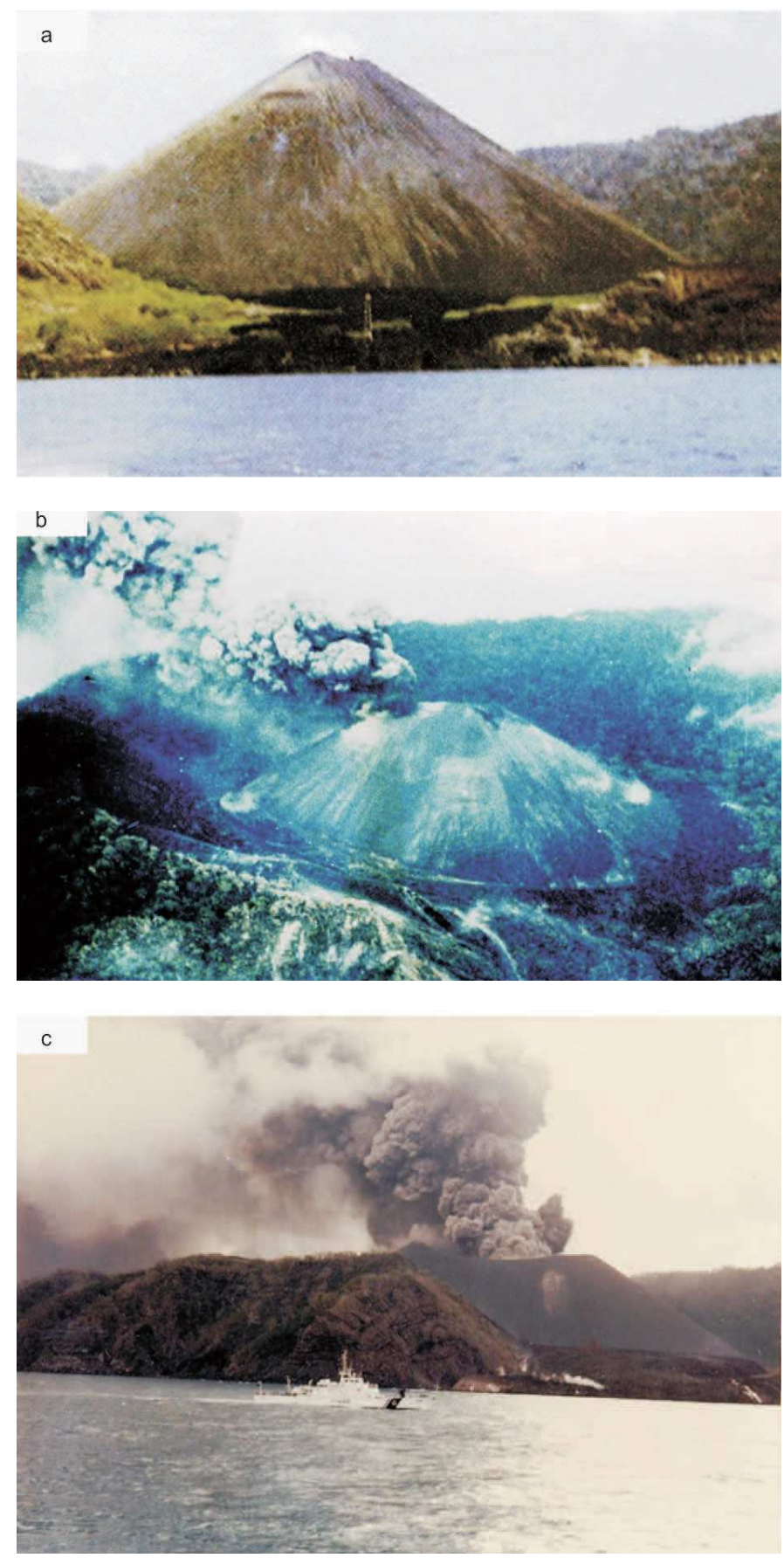

Figure 4. The historic volcano and characteristics of the recent eruptions, 1991, Barren Island. (a) Historic cinder-scoria cone in a dormant state and the historic basaltic lava flow field as observed in March 1990. (b) An aerial view of the perfectly symmetrical cinder cone of the historic volcano showing a flank eruption in early May 1991. Note the emission of a low height and loosely convoluted grey ash plume from a subsidiary vent below the summit crater and drifting of ash cloud by the prevailing northerly blowing wind. Image courtesy of the Indian Coast Guard, Port Blair. (c) Violent Strombolian eruption during August 1991 showing voluminous discharge of ash dispersed in gas (more appropriately called an ash eruption) from the summit crater that instead of a symmetrical cone of the early 1991 appear to be a bowl-shaped depression with lowering of height and enlargement of diameter, ship on the Andaman Sea provides a scale. 

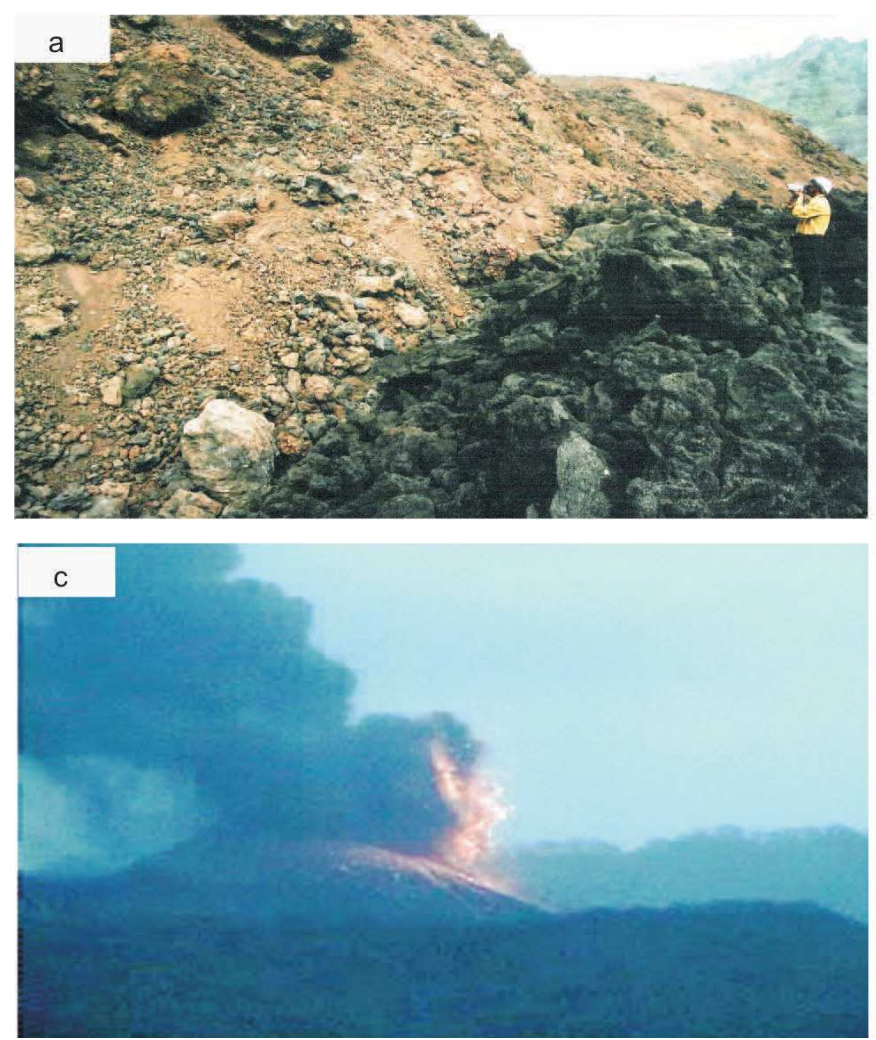

Figure 5. The summit eruptions during 2005 and their characteristics. (a) The craggy slope of the reddish tephra mound and the adjacent lava field from the southern part of the reactivated historic scoria cone. Note the angular and assorted lithic (reddish) material of recycled origin juxtaposed adjacent to jet black historic lava flows consisting of loose aggregate of angular, blocky fragments of basalt; person with video camera is for scale; a black solid square in Fig. $5 d$ (middle right) indicates the location from where video was made. (b) Violent Strombolian eruption from summit crater during June 2005 characterized by multiple and sustained eruption column events and discharge of voluminous amount of ash, gas and larger tephra fallen on the outer slope of the crater. Width of the view is approximately 200m. (c) Exposure of the Strombolian eruption of several seconds exhibits transient flames of fire in the backdrop of high flung ash plume during June 2005. (d) Aerial view of the Barren Island from the west in June 2005 shows on-going eruption from the historic cone. Note that the cone grew to become a conical hill from a bowl-shaped depression as observed during 1991 eruption (Figure. 4c). Note the intact preservation of extent and outcrop pattern of the historic lava flows mapped by Hobday and Mallet. The sub-vertical eruption plume shows an umbrella of ash clouds over the head of the plume and drifting of clouds towards the north. The recently erupted ballistic clasts can be seen as a reddish apron on the slope of the southern side of the active scoria cone and as a mound like deposit of assorted tephra at the base of the slope (marked with dashed lines). The northern side of the active cone shows conical hills of ash. (e) Aerial view of July 2005 displays forceful ejection of white stream and formation of steam plumes at the landing site but no active outpouring of lavas. Image $(d \&$ e) courtesy of the Indian Coast Guard, Port Blair.

outburst of ballistic clasts. A visit to the Island on $8^{\text {th }}$ January 2009 revealed an identical nature and style of eruption to those observed during strong eruptions in 1991 and 2005. Formation of a thick and dense eruption column were observed on each occasion yet collapse of the column and generation of pyroclastic surge flows was not seen. Satellite imagery, SIGMAT notices and pilot observations between January and September 2009 recorded maximum altitude of $3 \mathrm{~km}$ of the ash plumes (http:// Bom.gov.au/info/vaac/; http://www. hotspot.higp.hawaii.edu/).

Repeated observations of the eruptions during the current activity also provided an opportunity to document the characteristics of the
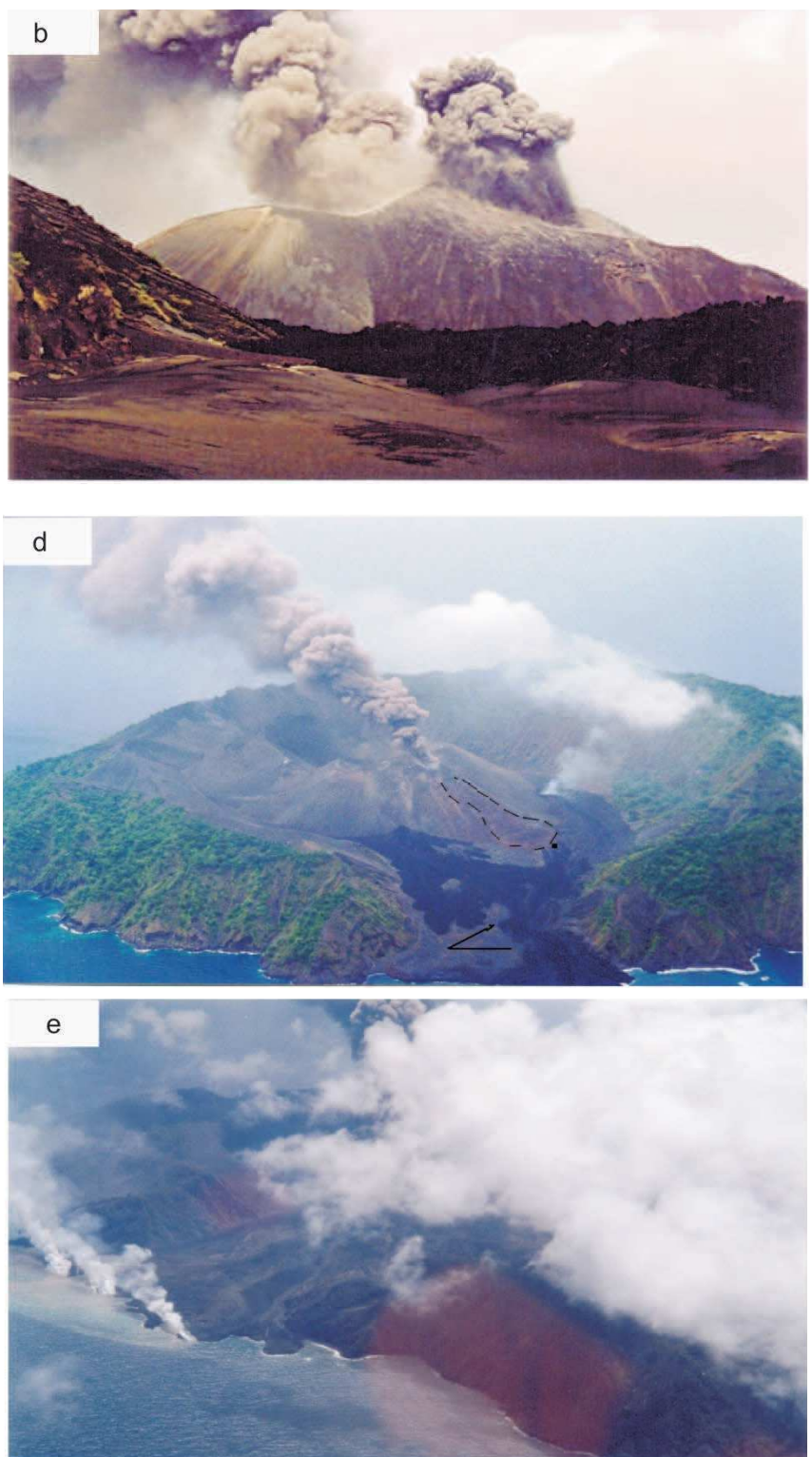


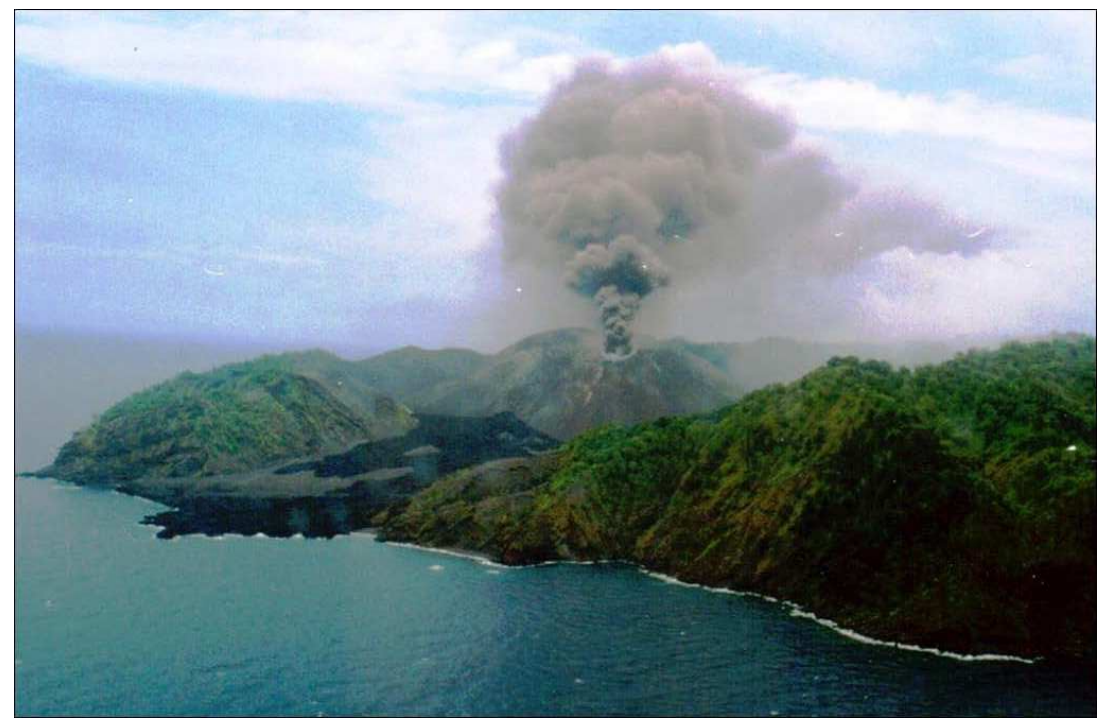

Figure 6. Aerial view shows eruptions from further west during June 2005. Note the fully exposed lava tongue and details of lobed end meeting the sea. The eruption column is near-vertical and consists of thick ash plume above the summit crater, an ash umbrella over the head of plume and northward drifting of ash cloud by the prevailing wind. This photograph provides a fair idea of the height of the eruption column that appears to be less than 500m given the height of the scoria cone is $\sim 300 \mathrm{~m}$. Image courtesy of the Indian Coast Guard, Port Blair

incorporation of cooled air the column becomes loosely convoluted, less dense and lighter coloured that, at the level of neutral buoyancy, produces an umbrella of ash clouds and lateral drifting of ash by the prevailing wind (Fig. 6).

The Barren Island ash emissions during the last two decades were not widely dispersed and were mostly deposited within the Island. On one occasion (March 2006) the ash drifted towards the west and was deposited on a ship at a distance of about $2 \mathrm{~km}$ west of the island. The Bulletin of the Global Volcanism Network (BGVN) monthly summary reports recorded a travel distance of up to $110 \mathrm{~km}$ for the Barren ash (Smithsonian Institution, 2005. Macdonald Island, Bulletin of the Global Volcanism Network, 30, no. 6).

\section{Eruptive Products and Landforms}

The eruptive products are ash, lapilli and subordinate amounts of larger ballistic clasts. The ash and lapilli accumulated away from the vent and also downwind to form cones rising to about 200-250 metres (Fig. 7a). Elsewhere, the finer ashes blanketed the topography and formed mantle bedding (Cas and Wright, 1987). The brownish black to yellowish brown ash and lapilli deposits show parallel-laminated, moderately sorted and moderate to well stratified layers of mm-thick ash alternating with $\mathrm{cm}$ - to $\mathrm{dm}$-thick layers of poorly-vesiculated lapilli (Fig. 7b) forming an up to 3 metre thick sequence. Similar mafic scoria-fall and ash-fall deposits representing the products of several episodes of explosive eruptions form part of the tephrostratigraphy of the Quaternary Aso volcano of Japan (Miyabuchi, 2009).

The Barren Island ballistic clasts are $10 \mathrm{~cm}$ to $50 \mathrm{~cm}$ in diameter and rarely up to one metre. They are mostly reddish lithic blocks of coarsely crystalline basalt recycled from the previous volcanic edifice. Such reddish fragments of variable sizes and shapes accumulated over the slope and at the base of the southern flank of the active scoria cone (Fig. 5d) and formed mounds of highly assorted tephra.
The craggy slope of the reddish tephra mound stands in sharp contrast to the black and unaltered historic lava flows (Fig. 5a). The ballistic clasts are in general angular. However, a few tend to be spherical and their surfaces are smooth (Fig. 7c), resembling ball-shaped volcanic bombs. The ash-lapilli matrix below the balls does not show any impact sag structures (Fig. 7c). Cauliflower bread-crust bombs, also reported to be abundant in pyroclastic flow deposit of Nakadake, Aso volcano, Japan (Miyabuchi et al., 2006), were collected (Fig. 2f of Bandopadhyay et al., 2006) from a loosely aggregated reddish tephra mound (Fig. 5a). The farvent ash/lapilli deposits at Barren Island correspond to the mid-distal facies while near-vent deposits of ballistic clasts on the slope of the central cone correspond to the proximal facies of Valentine and Gregg (2008). They represent deposit of violent Strombolian and true Strombolian eruptions respectively. Impact sag structures, pyroclastic surge deposits, accretionary lapilli, soft sediment deformation structures and adhesion of wet tephra on steeply inclined surfaces, which are indicative of phreatomagmatic explosions (Houghton and Hackett, 1984; Houghton \& Schmincke, 1986) and welding and rheomorphic textural features indicative of emplacement in hot state (Thordarson and Self, 1993; Bandopadhyay, 2004; Valentine and Gregg, 2008) were not found by the present authors nor reported in previous studies.

There was remobilization of volcanic material that filled the sandy alluvial ground (Fig.3), possibly triggered by earthquakes of moderate intensity that affected the area around Barren Island between November 2005 and January 2006 (Sheth et al., 2009). The material, consists of a loose accumulation of extremely heterogeneous large and small reddish and moulded chunks of lava, angular blocks of hardened lava from the prehistoric stratocone and black clinkers of the historic lava (Fig. 7d). This deposit blocked the landing site and the approach route to the volcano. The sharply angular, large and small blocks ( $\mathrm{cm}$ to a few metres in diameter) of light grey, sparsely vesiculated lava constitute rock fall deposits (inset in Fig. 7d).

\section{Historic and Prehistoric Landforms}

Barren Island is a composite volcanic system consisting of a prehistoric caldera and historic (post-caldera) central cone, similar to Aso volcano in Japan (Miyabuchi, 2009). The historic volcanic landforms in the Barren Island consist of a symmetrical scoria cone and basaltic lava that flows all the way to the sea (Fig. 2). The cone occurs at the centre of the amphitheatre, about $305 \mathrm{~m}$ high and a basal diameter of about $0.8 \mathrm{~km}$. The central cone is constructed of loose black ash, thought to have been erupted several times between 1787 and 1832 (Hobday and Mallet, 1885). These authors observed that basaltic gravel and rubble occupied the inside of the crater and largely filled the floor. They mapped and described basaltic aa lava that almost surrounds the volcanic cone, and one lava stream that extended from the western slope to reach the sea through the breach on the western wall of the ridge (Fig. 2).

The historic lava flows that encircle the scoria cone do not represent the lava flows of the 1990-91 eruption as reported in some studies (Shankar et al., 2001 and subsequent studies). The black 

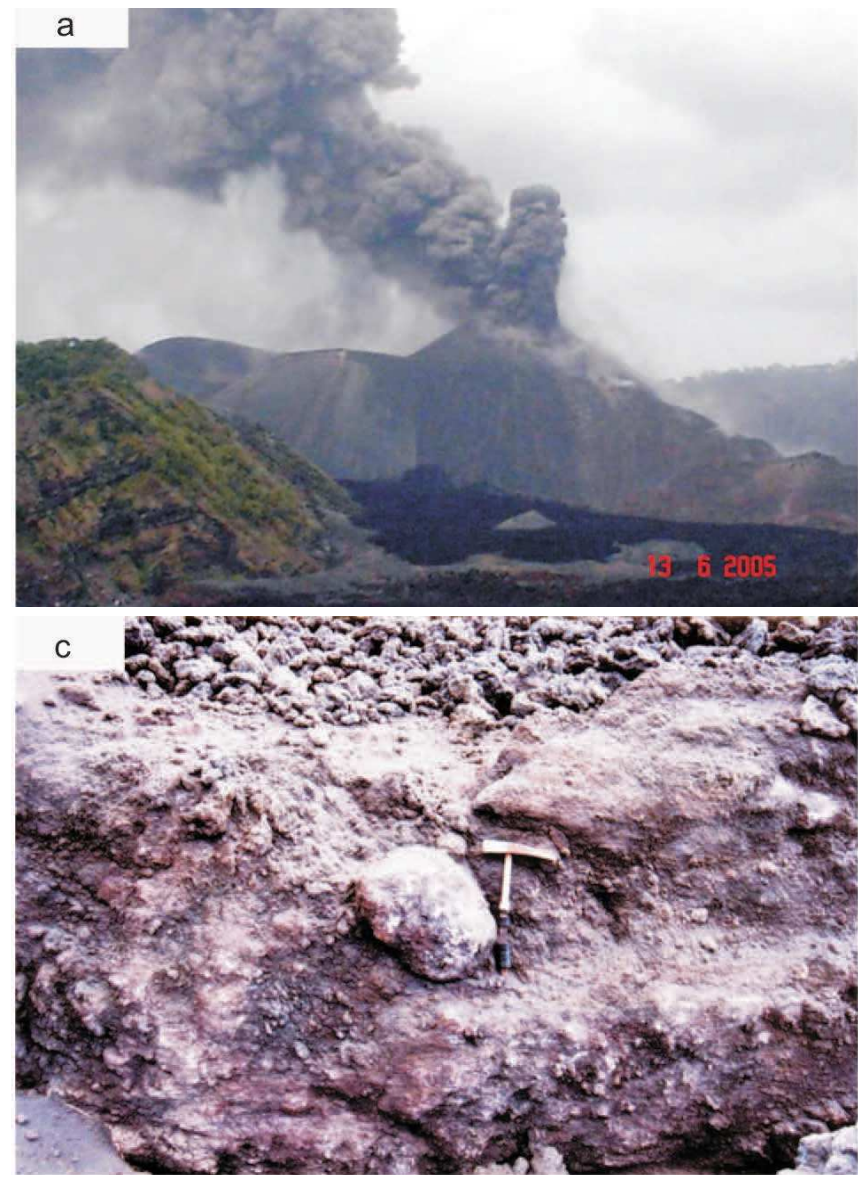
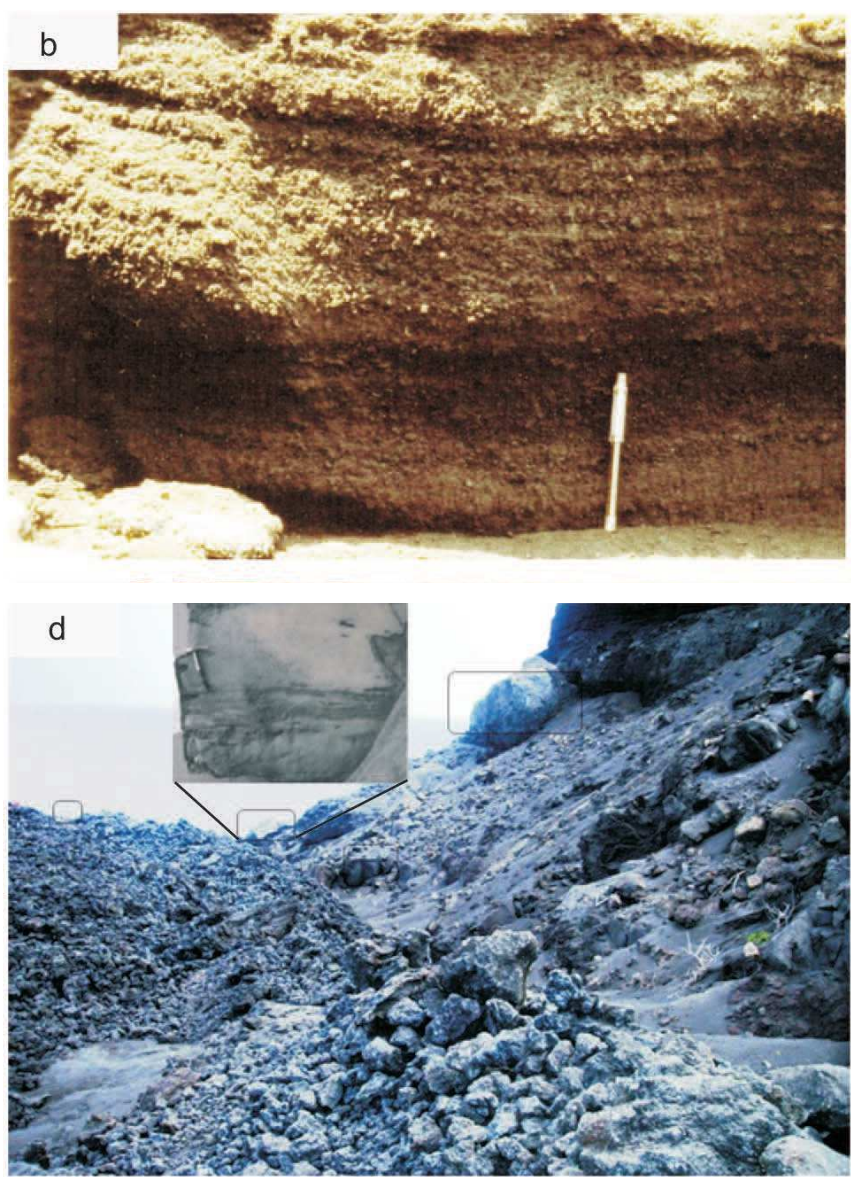

Figure 7. Deposits of the recent eruptions. (a) Lofty ash cones show deposition of ash to the down wind northern side of the active scoria cone. The eruption shows violent form of Strombolian explosion and cannon-like jets of gas thrust just above the crater; view from the west. Width of the view is approximately $20 \mathrm{~m}$. (b) Parallel stratified alternating layers of lapilli-rich and lapilli-poor coarse-grained and sorted air-fall ashes formed during the recent eruption. Pen is $14 \mathrm{~cm}$ long. (c) Smooth-surface spherical bomb partly embedded in assorted and non-stratified ash-lapilli matrix lacking any impact sag structure. Hammer handle is $25 \mathrm{~cm}$ long. (d) Deposits of tephra of different eruptions filled the narrow stretch and blocked the landing site shown in fig 3 between June 2005 and March 2006. Boulders and blocks of hardened lava of prehistoric stratocone (marked with rounded rectangle) lying scattered on the slope and at the shore, representing rock fall (inset shows a close-up of one rock fall block). Clinkery historic a lava flows jet black in colour occur on the left side. The foreground is occupied by reddish lithic fragments remobilized from upper slope. Field of view is approximately $40 \mathrm{~m}$.

clinkery aa lavas have jagged and spiked top surfaces exhibiting deep fractures and are totally bare of vegetation. Hobday and Mallet (1885) recorded the thickness of the flows reached up to 6 metres and the flow surfaces dip up to $30^{\circ}$ in all directions. During field visit in 2005 the aa lava flows were barren of vegetation. This is because the highly porous nature and fractured surfaces of the historic aa lavas permit rapid percolation of rain water through the rocks and thus preclude soil formation and growth of vegetation over the surface of the lava flows. Sheth et al. (2009) also mentioned that the historic cinder cone on Barren Island remained intact without any erosion, between an historic eruption which ended in 1832 and the initiation of recent eruptions in 1991. These authors stated that the cinder cone managed to survive erosion because cinder cones are in general well sorted and highly permeable rendering slow erosion because of little surface runoff.

The prehistoric landform comprises a stratocone with a summit crater about $\sim 2.0 \mathrm{~km}$ in diameter. Hobday and Mallet (1885) suggested that the summit crater was formed during a great explosive eruption. Shankar et al. (2001) described the crater as caldera and attributed its origin to a paroxysmal event. Chandrasekharam et al. (2009) suggested a non-eruptive lateral landslide of the original cone as the most probable caldera forming process. The vertical collapse of a magma chamber is the fundamental aspect of caldera forming events that give rise to the structural characteristics such as ring faults and a coherent subsided floor (Geshi et al., 2002; Nakada et al., 2005). Hobday and Mallet (1885) noted that the height of the circular ridge is much lower in the northwest than the southeast and attributed this difference to subsidence related to faulting. Sheth et al. (2009) suggested there are indications of a complete phreatomagmatic tephra ring around the exposed base of the volcano and that the caldera of Barren Island is bounded by a ring fault. Presence of a crater $(\sim 2.0$ $\mathrm{km}$ diameter) with a coherent floor and of ring faults confirms that the $2 \mathrm{~km}$ diameter depression is a caldera and that vertical collapse may be the reason for its formation.

The prehistoric stratocone is a moderately steep composite cone constructed of stratified volcanic rocks (Fig. 8a). The presence of steep scarp faces on its outer slopes possibly suggests that sectorcollapses have occurred (Fig. 8a). Such collapses are a common feature of some stratocones (Favallim et al., 2005). Stratocone profiles show alternating layers of lava and ash (Fig. 8a). The stratocone encloses a 

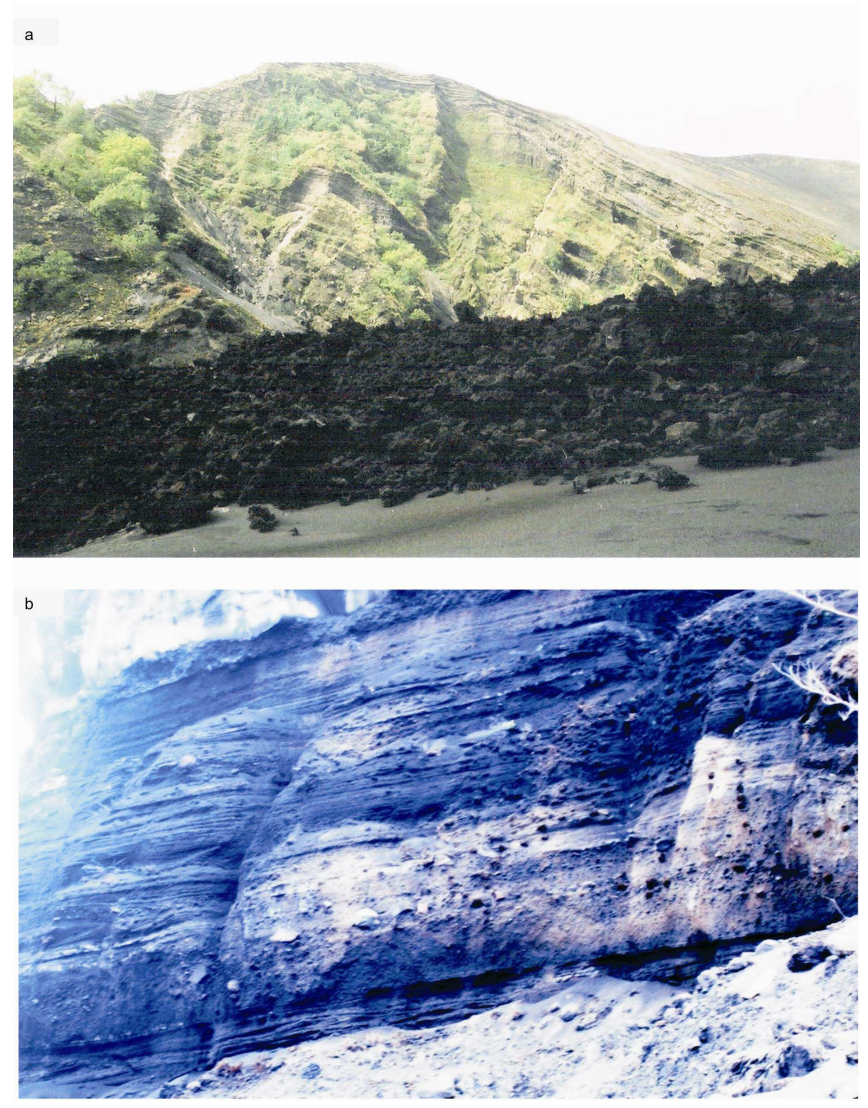

Figure 8. Prehistoric stratocone volcano. (a) Stratocone in the background stands as a succession of well stratified lava and fragmentary ejecta. Several scars partly covered with vegetation bear evidence of sector collapses possibly occurred during formation of the central depression. Steep sided rampart surface of the historic lava is seen in the foreground. The lava stack is $\sim 3 m$ thick. (b) Vertical cliff section of the Prehistoric stratocone exposes interstratified hardened lava and fragmentary ejecta. Flat planar, wavy, non-planar and lenticular interstratifications characterize the sequence of fragmentary ejecta of tuff and lapilli and block bearing tuff. The section is $\sim 20 \mathrm{~m}$ thick and is located near the landing site.

large circular depression (amphitheatre), $\sim 2.0 \mathrm{~km}$ across and 250 to 350 metres deep (Fig. 2). The stratified prehistoric volcanic succession (Fig. 8b) is best exposed on the northern inner caldera wall and comprised of interbedded lavas c. 10-200 cm thick and cm to dmthick ash to lapilli grade tephra beds containing abundant small and large ballistically emplaced angular blocks. Chandrasekharam et al. (2009) identified several sequences of eruption when studying the stratocone sections and outcrops. In a more detailed study, Sheth et al. (2009) logged several sections of the stratocone and described the prehistoric volcanic deposits which are comprised of pre-caldera tuff breccias, ash beds, aa lava flows and possible syn-caldera tuff breccias above the lava flows. Inferred cross-stratified ash beds in the stratocone sections, previously described as aeolian in origin (Shankar et al., 2001), were re-interpreted as pyroclastic surge flows by Sheth et al. (2009).

\section{Petrography of Barren ash}

Fine- to medium- sand size, uncontaminated air-fall ash samples collected from the deck of a ship during the 2006 eruption and were examined using petrographic and Scanning Electron (SEM) microscopes. Petrographic and heavy-mineral analyses were carried out at the University of Milano-Bicocca, Italy. The SEM study was carried out at the SEM Laboratory, Geological Survey of India, Kolkata.

High-resolution petrographic analyses were carried out by counting 400 points in each thin section by the Gazzi-Dickinson method. Following a simple nomenclature scheme, samples were classified according to their main components $(\mathrm{Q}=$ quartz; $\mathrm{F}=$ feldspars; $\mathrm{L}=$ lithic fragments), considered if exceeding $10 \% \mathrm{QFL}$, and listed in order of abundance. Heavy-mineral analyses were performed on a quartered aliquot of the 32-355 $\mu$ m class obtained by dry-sieving. Heavy minerals were separated by centrifuging in Na polytungstate (density $2.90 \mathrm{~g} / \mathrm{cm}^{3}$ ), and recovered by partial freezing with liquid nitrogen. On grain mounts, 200 transparent heavy-mineral grains were counted by the area method (all samples are rich in volcanic glass or altered grains). Heavy-mineral concentrations were calculated as the volume percentage of total (HMC) and transparent (tHMC) heavy minerals (Garzanti and Andò, 2007a, b).

Barren Island, heavy-mineral assemblages of air-fall ash samples range from "moderately poor" $(1=\mathrm{HMC}<2)$ to "moderately rich" $(2=\mathrm{HMC}<5)$. Detrital components are listed in order of abundance throughout the text. Apart from determining the petrographic and heavy mineral compositions, it was also our aim to search for Pele's tears, Pele's hair and reticulate fragments all commonly present in, but not diagnostic of, Hawaiian eruptions (Heiken and Wohletz, 1992; Fisher and Schmincke, 1984). None were found. Lithic ash grains are predominant in the samples and these are mostly black in colour, angular, occasionally blocky, poorly to moderately vesicular and the vesicles are relatively large (Figs. 9a, b). SEM images of ash grains also show curvilinear broken outer surfaces of vesicles (Fig. 9b). Many ash samples have adhering particles on their surfaces and also inside the vesicle-hollows similar to those documented from Aso volcano (Miyabuchi et al., 2006). The modal compositions of three ash samples are given in Table 1. The framework mode (QFL) in all the samples show high percentage of volcanic lithic grains (84-87\%) followed by plagioclase making up 16 to $13 \%$ (Figs. 10a, b, c, d) while moderately poor to moderately rich heavy mineral suites are dominated by olivine and subordinate green-augitic clinopyroxene (Table 1), reflecting a basaltic composition. Plagioclase phenocrysts are most abundant. Luhr and Haldar (2006) also made similar observation. Many plagioclase phenocrysts are fresh, tabular, whole or broken euhedra, show thick and multiple twinning, zoning and also contain inclusions of glass (Fig. 10a). Haldar and Luhr (2003) reported that zoning in plagioclase megacrysts is commonly normal and rarely reverse. Many lithic volcanic (Lv) fragments contain large euhedral pyroxene and olivine phenocrysts embedded in basaltic glass (Figs. $10 b, c)$. Garzanti et al (2013) also analyzed modern sands collected from the beaches of Barren and Narcondam Islands and mentioned that neovolcanic detritus characterizes the Barren Island samples that are mostly feldspatho-lithic, with exclusively lathwork grains and a moderately rich, olivine-dominated suite with common clinopyroxene and no amphibole. Heavy mineral suites of the studied ash samples are olivine-dominated with subordinate augitic clinopyroxene (Fig. $11 \mathrm{a}, \mathrm{b})$. All but a few of the Barren Island ash samples do not resemble those resulting from phreatomagmatic activity (Geshi and Okiwaka, 2008). 

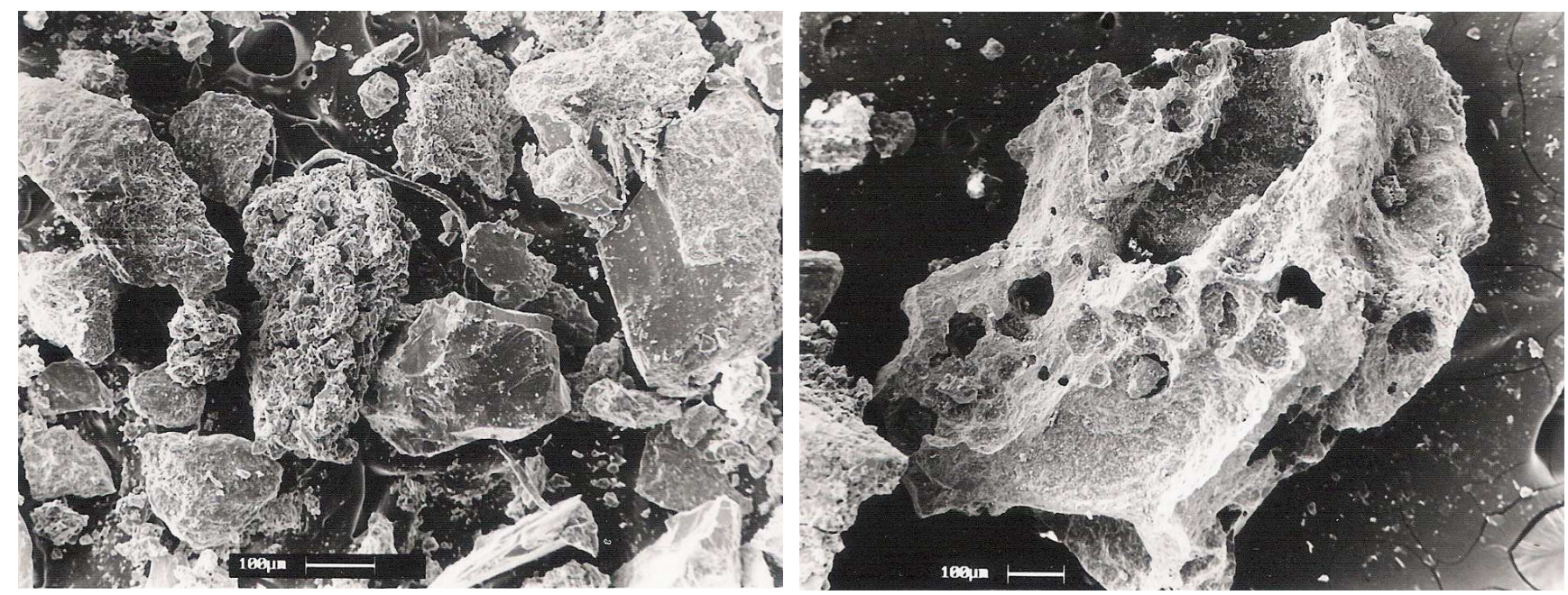

Figure 9. SEM images of ash samples. (a) Non-vesicular ashes show assorted mixture of grains of different sizes. Note blocky ash grain on the right side. (b) Vesicular ash grain showing impression of outer surfaces of vesicles.

\section{Discussion}

Throughout its recent history, Barren Island volcanic activity has been characterized by (a) central vent type eruptions, (b) significant discharges of ash dispersed in gas, (c) ejection of oxidized scoria (reddish lithic fragments), (d) development of sustained eruption plumes $<1 \mathrm{~km}$ in elevation, (e) small ash dispersal area, (f) formation of a scoria cone and mantle bedding, (g) rumbling, bursting and clattering sounds and, (h) absence of sustained jetting or outpouring of lava flows. These attributes suggest Strombolian and violent Strombolian explosions (Parfitt, 2004; Martin and Nemeth, 2006; Valentine and Gregg, 2008). Previous interpretations have suggested Hawaiian, Plinian/sub-Plinian and Vulcanian styles of eruption (Shankar et al., 2001; Chandrasekharam et al., 2009; Sheth et al., 2009) but these are unlikely. Based on visual estimation Haldar and Luhr (2003) stated a maximum eruption column height of not more than $3 \mathrm{~km}$ even though they described the eruption as a Plinian type. The average minimum height for a Plinian eruption is c. $\sim 10 \mathrm{~km}$ (Valentine and Gregg, 2008). Sheth et al. (2009) also described the climactic stage of 1991 eruptions as sub-Plinian stating that the eruption column rapidly increased to a height up to $1 \mathrm{~km}$. Pal et al. (2010) described the 2005-2006 eruptions as Strombolian to sub-Plinian. An example of a low-height sub-Plinian eruption from the Furmas volcano shows that the eruption column rose to a height varying between 9 and $17 \mathrm{~km}$ (Cole et al., 1999). Therefore, the height of the eruption column during the current activity on Barren Island does not suggest a sub-Plinian type. Moreover, Plinian and sub-Plinian eruptions often penetrate the stratosphere and have potential impacts over much larger region and even globally (Valentine and Gregg, 2008). The Barren ash

Table 1. Framework mode (QFL) of Barren Island ash samples showing high percentage of volcanic lithic grains (84-87\%) while moderately poor to moderately rich heavy mineral suites are dominated by olivine and subordinate clinopyroxene, reflecting basaltic composition.

\begin{tabular}{|c|c|c|c|c|c|c|c|c|c|c|c|c|c|c|c|c|c|c|}
\hline & & 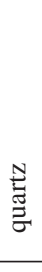 & 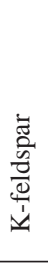 & $\begin{array}{l}0 \\
\frac{0}{0} \\
\frac{0}{0} \\
\frac{\pi}{00} \\
\frac{\pi}{2}\end{array}$ & 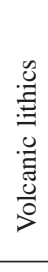 & 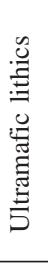 & 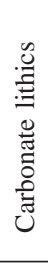 & 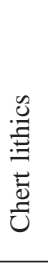 & 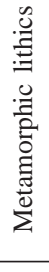 & & HMC & HMC & $\stackrel{\mathscr{N}}{\mathrm{N}}$ & 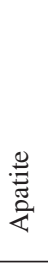 & 苛 & 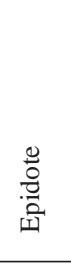 & $\underset{\stackrel{\Xi}{\Xi}}{\mathbb{E}}$ & $\begin{array}{l}\frac{\overrightarrow{0}}{0} \\
\stackrel{0}{0} \\
\frac{0}{0}\end{array}$ \\
\hline Barren Island & BA1 & 0 & 0 & 16 & 84 & 0 & 0 & 0 & 0 & 100.0 & 2.5 & 1.3 & 0 & 0 & 0 & 0 & 0 & 0 \\
\hline Barren Island & BA2 & & & & & & & & & & & & 1 & 0 & 0 & 2 & 0 & 0 \\
\hline Barrem Island & BA3 & 0 & 0 & 13 & 87 & 0 & 0 & 0 & 0 & 100.0 & 3.8 & 2.8 & 0 & 0 & 0 & 0 & 0 & 0 \\
\hline & & 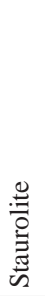 & 莺 & 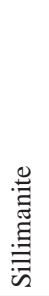 & 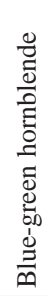 & 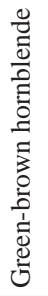 & 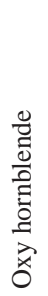 & 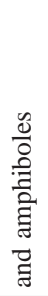 & 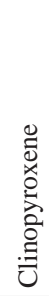 & 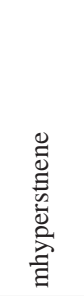 & 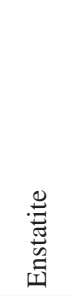 & 竞 & 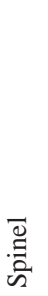 & $\begin{array}{l}\frac{n}{0} \\
\stackrel{ \pm}{0}\end{array}$ & & 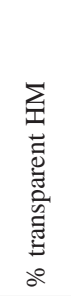 & 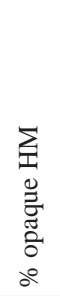 & 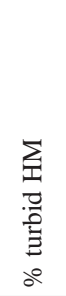 \\
\hline Barren Island & BA1 & 0 & 0 & 0 & 0 & 0 & 0 & 0 & 29 & 0 & 0 & 71 & 0 & 0 & 100.0 & $54 \%$ & $0 \%$ & $46 \%$ \\
\hline Barren Island & BA2 & 0 & 0 & 0 & 0 & 0 & 0 & 0 & 45 & 1 & 0 & 52 & 0 & 0 & 100.0 & $44 \%$ & $0 \%$ & $56 \%$ \\
\hline Barrem Island & BA3 & 0 & 0 & 0 & 0 & 0 & 0 & 0 & 0 & 0 & 0 & 91 & 0 & 0 & 100.0 & $73 \%$ & $0 \%$ & $26 \%$ \\
\hline
\end{tabular}



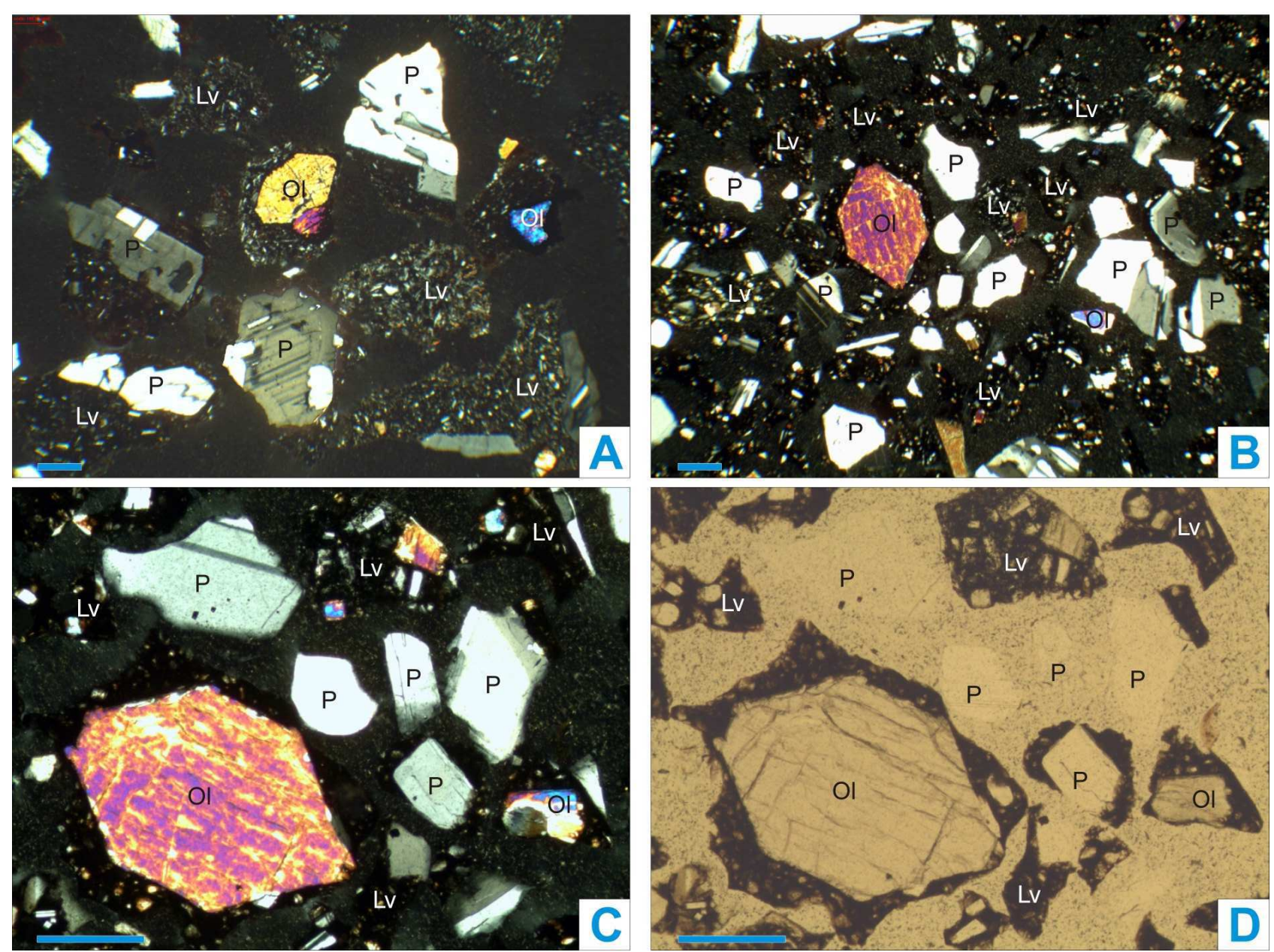

Figure 10. Petrography of Barren Island air-fall ash samples (photos A, B, C with crossed polars; blue bar = 250 $\mu m$ ). P = plagioclase; $L v=$ volcanic lithic grains; $\mathrm{Ol}=$ olivine. A) Plagioclase phenocrysts show thick and multiple twinning, zoning and inclusions of glass. B, $C$, D) Lithic fragments contain large euhedral olivine phenocrysts embedded in basaltic glass. Many plagioclase phenocrysts are present. Note the dominance of lithic grains in ash samples.

plume was much lower (c. $1 \mathrm{~km})$ and had limited dispersal.

Influx of material from a volcano is another measure of classifying eruptions (Parfitt, 2004; Valentine and Gregg, 2008). In this respect, an estimated $\sim 8$ million $\mathrm{m}^{3}$ of material is considered to have been erupted during 1991 activity (Sheth et al., 2009) which is consistent with a Strombolian eruption (Valentine and Gregg, 2008). The transient reddish glow of fire over the mouth of the summit crater described as a lava fountain (Haldar et al., 1992; Haldar and Luhr, 2003) may more correctly be described as a fire fountain. Therefore, the height of the eruption column, the transient flash of light, the volume of material discharged and the area of ash dispersal all collectively argue against a Plinian/sub-Plinian mode of eruption. Scoria cones, the most common landform formed by mild Strombolian explosions (Martin and Nemeth, 2006), occur on Barren Island and also suggest Strombolian activity. Cashman et al. (2000) stated that violent Strombolian eruptions produce voluminous ash and simultaneous lava effusion (see also Landi et al., 2006 and Lodato et al. 2007). There is also a general consensus that Strombolian eruptions rarely issue lavas (Schmincke, 2004). At Barren Island each eruptive event started with emission of light grey ash with or without accompanying phreatic white steam and quickly changed to a sustained eruption column with transient flame of fire accompanied by frequent showers of ballistic clasts. Before cessation the activity turned into mainly discrete explosions with or without a thin grey plume. This style of Strombolian activity, by and large, is consistent with initial ash and steam explosions of hydromagmatic origin that are normally followed by intermediate fire fountaining and Strombolian explosions, due to magmatic vesiculation. These culminate in a final, sustained phase of ash explosions, caused by over pressurization and pervasive fragmentation of the degassed and cooled top of the magma column at shallow depth (Taddeucci et al., 2004).

The production of significant quantities of ash is the most conspicuous feature of the recent Barren Island eruptions that raises the question whether the ash is magmatic or phreatomagmatic in origin (Macdonald, 1972). Buttner et al. (2002) suggested that one of the most efficient processes to produce fine volcanic ash is through magma-water interaction. Clearly such activity requires a water source. Involvement of caldera lakes was suggested to explain the phreatomagmatic activity at Furmas volcano (Cole et al., 1999). Initial phreatomagmatic phases are well documented in many Hawaiian and/ or Strombolian-type eruptions such as at the Laki fissure in Iceland (Thordarson and Self, 1993). Patrick et al. (2007) suggested that much of the ash in an eruption cloud could be generated by abrasion of already cooled and brittle clasts when they are recycled in the vent. Cole et al. (1999) suggested that the magmatic activity gives rise to lapilli-fall whereas phreatomagmatic activity produces ash-fall, 

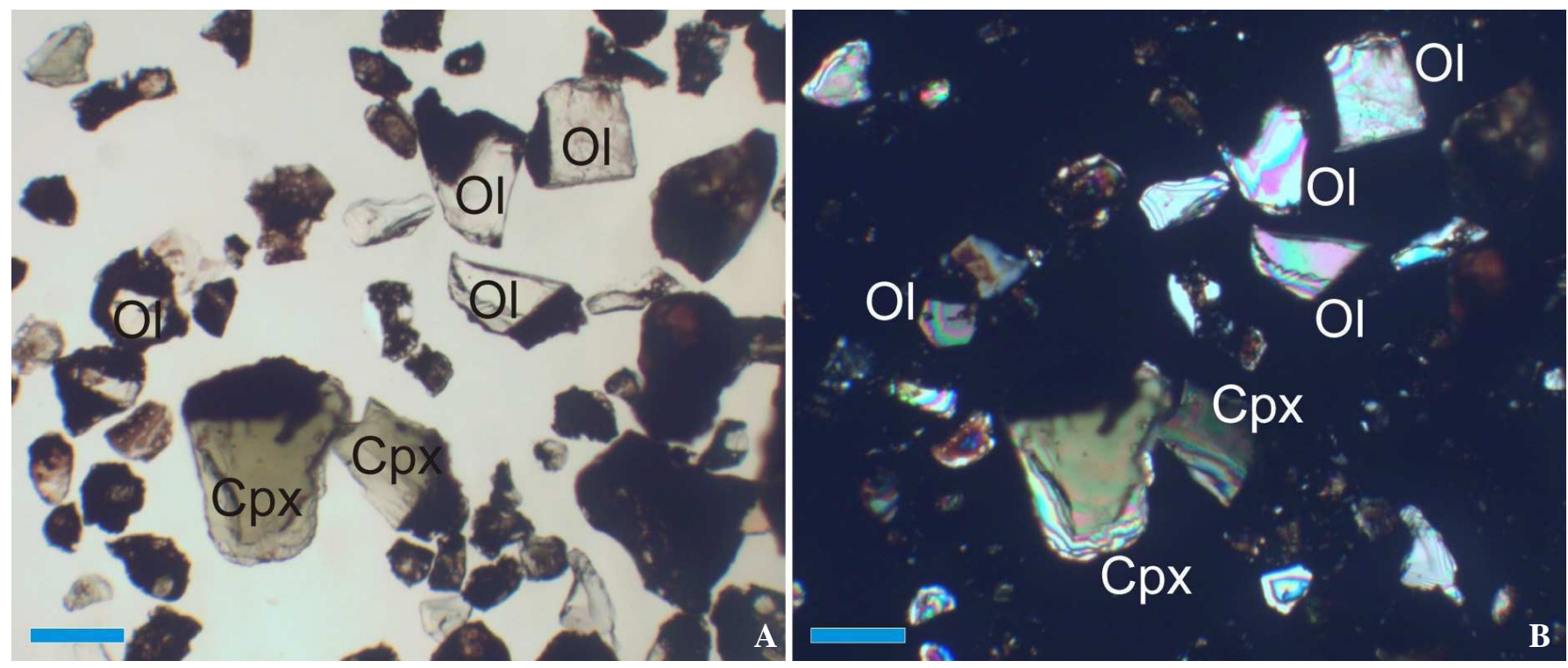

Figure 11. Heavy-mineral suite of air-fall ash samples from Barren Island (A under plane polar, B under crossed polars; blue bar = 250

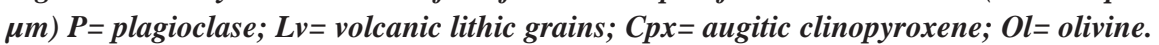

pyroclastic surges and flows. Clasts with variable degree of palagonitisation and poorly sorted pyroclastic air-fall and surge deposits are typical of phreatomagmatic activity (Houghton and Hackett, 1984). Despite several field visits at Barren Island, pyroclastic surge and flow deposits, impact sag structures, accretionary lapilli, etc have not been recognized so far and there is no evidence of a crater lake in this small Island. Ash grains with blocky shapes in Barren Island ash samples, however, could be the product of phreatomagmatic action (Heinken and Wohletz, 1992). The blocky morphology though uncommon in Barren Island ash samples indicates brittle fracturing of the grains. Miyabuchi et al. (2006) suggested that the blocky shape results from chilling and fragmentation when magma mixes with external water. Therefore, magmatic processes may be the key factor for the generation of Barren Island volcanic ash but contributions from phreatomagmatic processes cannot entirely be ruled out. An interpretation of slow cooling of the melt at a shallow depth, based on the presence of abundant phenocrysts, is consistent to that of Luhr and Haldar (2006). A slow rate of magma rise would permit rapid formation of a separate gas phase, accumulation of gas bubbles at the upper cooled surface of the magma column, and eventual bursting of those bubbles resulting in ejection of partly molten and solid fragments of lava and magmatic gases (Houghton et al., 1999; Martin and Nemeth, 2006). However, the depth and precise mechanism of generation of the gas phase in the magma column, discussed in detail by Parfitt (2004), for Barren Island is not known. Luhr and Haldar (2006) based on petrographic study of lava clasts, identified several Barren Island lava samples that contain disaggregated troctolitic (olivine + plagioclase) cumulates, indicating derivation from a shallow magma chamber under the volcano.

The reported occurrences of active lava flows during the recent eruptions remain a contentious issue. Haldar et al. $(1992,1999)$ described voluminous lava flows during the 1991 and 1994-1995 eruptions. Chandrasekharam et al. (2009) delineated the different flows in their map as occurring in 1991, 1995, 2005 etc and constructed a flow stratigraphy (Figs. 4 and 5 of Chandrasekharam et al., 2009). Sheth et al. (2009) also mapped lava flows ascribed to
1991, 1994-95 and 2005-06 eruptions. In view of the absence of unambiguous evidence such as convincing photographs of the active lava flows, documents pertaining to real-time monitoring of the lava flow events, and lack of thermal images or field/structural attributes as illustrated in other studies (Calvari et al., 2006; Lodato et al., 2007), it is difficult to accept the above contentions. Bandopadhyay et al. (2006) interpreted the recent activity as mild Strombolian eruptions virtually lacking lava flows. Haldar and co-workers, including the first author, observed the episodes during eruptions since 1991, but there has been no regular monitoring of the activity during any of the cycles (1991, 1994-95, 2005-06, 2009 etc). It is, therefore, impractical to identify and characterize the different lava flows. It is also problematic when the recent incidences (1991, 1994-95 and 200506) of active lava flows (as has been claimed) occurred in quick successions. Delineation of active lava flows of different cycles on the map (Sheth et al., 2009) without describing the basis leaves scope for re-examination. Further, none of the earlier studies paid due attention to the presence of historic lava to understand the incidences of active lava flows, instead suggesting that the historic lava flows were totally buried under recent flows (Haldar and Luhr, 2003; Luhr and Haldar, 2006; Sheth et al., 2009). But, contrary to such findings, the first author during the field study in June 2005 observed a nearly intact preservation of the historic lava flows mapped and described by Hobday and Mallet (1885) and a careful comparison between the map (Fig. 2) and the photographs (Figs. 5d and 6) of 2005 appears relevant. The necklace pattern of the historic lava flows mapped (Fig. 2) could easily be recognized, in its original shape and extent, in the aerial photograph of 2005 (Fig. 5d). A close match between the lava tongue and the lobed end of the tongue ending into the sea (Fig. 6) and the lava tongue mapped by Hobday and Mallet appears significant. Also there has hardly been any change in coastline configuration including the position of landing site marked in Figure 2 except destruction of the light house. These findings argue against the evidence provided in previous studies claiming the existence of active lava flows during the recent volcanic activity. Moreover, any 1991 and younger lavas would have taken the easiest route to flow to the breached western side of the island, which is not over the jagged and 
highly uneven historic lava surfaces. Outpouring of active lavas during March 2009 activity was inferred by Sheth et al. (2010). These authors described lavas, issuing out from an intermediate elevation on the cinder cone, instead from the summit crater, descending at a steep angle over the outer caldera wall cliff on the northern side of the island and meet the sea. They also suggested that the valley between cinder cone and the northern caldera wall that existed till April 2008 was completely filled up by the deposition of voluminous new ash between April 2008 and March 2009 that facilitated active lava flows towards north, instead of west. It is, however, difficult to accept that a blocky lava could flow over the accumulated loose ash that forms conical hills in the northern side. Moreover, reports of the Darwin Volcanic Ash Advisory Centre between July 2008 and March 2009 (See ref, Barren Island Volcanic Activity Database) reveals eruptions of ash and drifting of ash clouds, in most cases, towards the west and southwest by the prevailing wind. Therefore, deposition of voluminous ash towards the north in the valley between cinder cone and northern caldera wall, as suggested by Sheth et al. (2010), appears to have been impossible. They also showed steam plumes (Fig. 3c and 4a, b of Sheth et al., 2010) and interpreted them as a result of lavas entering into the sea but these might, rather, have been caused by pyroclastics entering the sea. Similar strong steam plumes without any secondary phreatic eruption were recorded in July 2005 that, as discussed earlier, was not associated with active lava front but, instead, possibly associated with hot spring activity. The undoubted signature of active lava flows such as coherent mass of molten rock material entering into the sea as a distinctly visible strip of bright incandescence glowing with reddish colour and often fuming brown gases (cf, Fig. 75 of BGVN report (04/2007(BVGN 32:04; Fig 2.2 of Shankar et al. 2001 and others) was never observed during the current activity nor documented in any previous studies. Therefore, the occurrence of active lava flows remains arguable because of 1) a lack of convincing documentation or real-time monitoring, or other field observations pertaining to active lava flows, 2) field studies carried out at Barren Island were for very short periods, 3 ) the current activity is essentially an ash plume (gas-rich) eruption with intermittent true Strombolian explosions that normally, although not necessarily, lacks lava flows, and 4) misinterpretation of historic lavas flows as the lava flows of the recent eruptions.

Identification of lava clasts of different eruptions such as 2005, 2006 (Pal et al., 2010) is conjectural in view of the fact that the erupted products of the Strombolian activity contain juvenile bombs mixed with cool, recycled blocks and lapilli (Valentine and Gregg, 2008). At Barren Island, coarsely crystalline blocks of basalt show reddish oxidized crust on their surfaces and were too cool on landing to weld or fuse (Fig. 5a). These are possibly derived from the previous volcanic edifice, the floor of which was filled with debris. The inclusion of these as juvenile products of the 2005-2006 eruptions (Pal et al., 2010) and linking petrological variations and evolution to specific eruptive phase in previous studies (Luhr and Haldar, 2006; Chandrasekharam et al., 2009; Pal et al., 2010) therefore, remain ambiguous.

\section{Conclusions}

This study critically reviews and discusses the existing knowledge on recent and past eruptions on Barren Island based on first-hand information. The authors conclude that the current volcanic activity has been true Strombolian and violent Strombolian eruptions that commonly lack active lava flows. The evidence in favour of active lava flows and the Hawaiian, Vulcanian and Plinian type of eruptions, suggested in previous studies remains unconvincing. The interpretation of this study is important in predicting the explosive/ effusive events of the post-2009 activity. This study records that the historic activity was Strombolian eruptions, switching to effusive lava flows while the caldera forming pre-historic activity was an alternating event of effusive and explosive eruptions. The eruptive history of the Barren volcano records the recurrence of activity since prehistoric time and thus confirms that the volcano is one of the most active volcanoes in the Western Sunda Arc. The history also records a temporal change in activity from alternating effusive and explosive eruptions to exclusively explosive eruptions especially in later events. This provides new insight into the volcanological evolution of Barren Island volcano and behavior of the volcano in future.

\section{Acknowledgements}

Prof. M. Jayananda had reviewed the paper critically and suggested important modifications. Editor of the journal also made a detailed review and advised us for improving the petrography section. These certainly helped to improve the content. Prof. H.C. Sheth reviewed the earlier versions of the paper and some of his comments also helped authors to improve the text and to tighten the loose arguments. We gratefully acknowledge their efforts. This research article is an outcome of a book writing project sponsored by DST, Govt of India to PCB under USERS scheme (file no. SB/UR/14/2012). The logistic support was provided by the department of geology, University of Calcutta. The authors thankfully acknowledge the financial and logistic supports received from these institutions. The Indian Coast Guard, Port Blair on all occasions provided the logistic support. Dr. T. Pal and S. Ragav of the Geological Survey of India (GSI) accompanied the author during field study at the Barren Island on June 2005 and March 2006. Mr. Surabhi Prasad Singh of Geodata division, Northern Region GSI has efficiently prepared the line drawings (map of and cooperation Barren Island and Western Sunda Arc). The author gratefully acknowledges the help.

\section{References}

Alam, M. A., Chandrasekharam, D., Vaselli, O., Capaccioni, B, Manetti, P., \& Santo, P.B. 2004, Petrology of the prehistoric lavas and dyke of the Barren Island, Andaman Sea, Indian Ocean. In: Magmatism in India through time, (eds H.C. Sheth, and K. Pande), Proceedings of the Indian Academy of Science (Earth Planet Science) v.113, pp. 715-721.

Awasthi, N., Ray, J. S., Laskar, A. H., Kumar, A., Sudhakar, M., Bhutani R., Sheth, H. C., Yadava, M. G., 2010, Major ash eruptions of Barren Island volcano (Andaman Sea) during the past $72 \mathrm{kyr}$ : clues from a sediment core record. Bulletin of Volcanology, v. 72, pp. 1131-1136, DOI 10.1007/ s00445-010-0408-1

Bandopadhyay, P. C., 2005, Discovery of abundant pyroclasts in Eocene Namunagarh Grit, South Andaman; evidence for arc volcanism and subduction during the Palaeogene in the Andaman area. Journal of Asian Earth Sciences v. 25, pp. 97-107.

Bandopadhyay, P. C., Mitra, S., Pal, T. and Ragav, S., 2006, The 2005 eruption on Barren Island, Andaman Sea. Current Science v. 90 no. 5, pp. 620622 .

Bandopadhyay, P. C., 2012, Re-interpretation of the age and environment of deposition of Paleogene turbidites in Andaman and Nicobar Islands; Western Sunda Arc. Journal of Asian Earth Sciences, v. 45, pp. 123-136.

Bandopadhyay, P. C., 2004. Proterozoic deep marine volcanic eruptive product 
(Obsidian glass) in Chanda Limestone: Its implications in basin evolution and metallogenesis. Gondwana Research, v. 7, pp. 613-619.

Barren Island Volcanic Activity Database - Smithsonian Institution, National Museum of Natural History, Global Volcanism Program (http:// www.volcano.si.edu/volcano.cfm?vn=260010) (Data Source Darwin Volcanic Ash Advisory Centre (VAAC)

Buttner, R., Dellino, P., La Volpe, L., Lorenz, B., and Zimanowski, B., 2002, Thermodynamic explosions in phreatomagmatic eruptions as evidenced by the comparison between pyroclasts and products from molten fuel coolant interaction experiment. Journal of Geophysical Research Solid Earth, v. 107, no. (B11), 2277 (art no).

Calvari, S., Sampinato, L. and Lodato, L., 2006, The April 2003 Vulcanian paroxysmal explosion at Stromboli volcano (Italy) from field observations and thermal data. Journal of Volcanology and Geothermal research, v.149, pp. 160-175.

Calvari,.S., Sampinato, L., Lodato, L., Harris, A. J. L., Patrick, A. R., Dehn, J., Burton, M. R. and Andronico, N. 2005, Chronology and complex volcanic processes during the 2002-2003 flank eruption at Stromboli volcano (Italy) reconstructed from direct observations and surveys with a handheld thermal camera. Journal of Geophysical Research, v. 110, pp.1231-1242.

Cas, R. A. F. and Wright, J. V., 1987, Volcanic successions, modern and ancient. Chapman and Hall, London, 528p.

Cashman, K.V., Sturtevant, B., Papale, P. and Navon, O., 2000, Magmatic fragmentation. In: Encyclopedia of volcanoes (eds Sigurdson et al.,) Academic Press, San Diego 421-430.

Chandrasekharam, D., Santo, A. P., Cappuccino, B., Vaselli, O., Manetti, P., Aalam, M. A., and Tassi, F., 2009, Volcanological and petrological evolution of Barren Island (Andaman Sea, Indian Ocean). Journal of Asian Earth Sciences v. 35, pp. 469-487.

Cole, P. D., Guest, J. E., Queiroz, G., Wallenstein, N., Pacheco, J. M., Gaspear, J. L., Ferreira, T. and Duncan, A.M., 1999, Styles of volcanism and volcanic hazards on Furnas volcano, Sao Miguel, Azores. Journal of Volcanology and Geothermal Research v. 92, pp. 39-53.

Curray, J. R., 2005, Tectonics and history of the Andaman Sea region. Journal of Asian Earth Sciences v. 25, pp. 187-232.

Favallim, M., Karatson, D., Mazzuoli, R., Pareschi, M.T. and Ventura, G. 2005, Volcanic geomorphology and tectonics of the Aeolian archipelago (southern Italy) based on integrated DEM data. Bulletin of Volcanology, v. 68 , pp. $157-170$.

Fisher, R. V., and Schmincke, H.-U., 1984, Pyroclastic rocks. Springer-Verlag, Berlin, 472pp.

Garzanti, E. and Andò, S., 2007a, Heavy-mineral concentration in modern sands: implications for provenance interpretation. In: Mange, M.A., Wright, D.T. (Eds.), Heavy Minerals in Use. Developments in Sedimentology Series, 58. Elsevier, Amsterdam, pp. 517-545.

Garzanti, E. and Andò, S., 2007b, Plate tectonics and heavy-mineral suites of modern sands. In: Mange, M.A., Wright, D.T. (Eds.), Heavy Minerals in Use. Developments in Sedimentology Series, 58. Elsevier, Amsterdam, pp. 741-763.

Garzanti, E., Limonta, M., Resentini, A., Bandopadhyay, P. C., Najman, Y., Ando, S. and Vezzoli, G., 2013, Sediment recycling at convergent plate margins (Indo-Burman Ranges and Andaman-Nicobar Ridge), v.123, pp.113-132.

Geshi, N. and Oikawa, T., 2008, Phreatomagmatic eruptions associated with the caldera collapse during the Miyakejima 2000 eruption, Japan. Journal of Volcanology and Geothermal Research, v. 176, pp. 457-468.

Geshi, N., Shimano, T., Chiba, T. and Nakada, S., 2002, Caldera collapse during the 2000 eruption Miyakejima volcano, Japan. Bulletin of Volcanology, v. 64, pp. 55-68.

Haldar, D., Laskar, T., Bandopadhyay, P. C., Sarkar, N., Biswas, J. K., 1992, Volcanic eruption of the Barren Island volcano, Andaman Sea. Journal of the Geological Society of India. V. 39, pp. 411-422.

Haldar, D., Chakraborty, S. C. and Chakraborty, P. P., 1999, The 1994-1995 eruption of the Barren Island volcano of the Andaman Sea, India: a resurgent volcanism. Gondwana Geological magazine, v. 4, pp. 371-384.
Haldar, D. and Luhr, J. F., 2003, The Barren Island volcanism during 1991 and 1994-95: eruptive style and lava petrology. Geological Society of India Memoir, no. 32, pp. 313-328.

Heiken, G. And Wohletz, K., 1992, Volcanic ash. Univ. California Press, Berkeley, CA. 246pp.

Hill, B. E., Connor, C. B., Jarzemba, M. S., La Fermina, P.C., Navarro, M. and Strauch, W., 1998, 1995 eruptions of Cerro Negro volcano, Nicaragua, and risk assessment for future eruptions. Geological Society of America Bulletin, v.110, pp. 1231-1241

Hobday, J. R. and Mallet, F. R., 1885, The volcanoes of the Barren Island and Narcondam in the Bay of Bengal; their topography by captain J. R. Hobday, S.C., and Geology by F. R. Mallet. Memoirs of the Geological Survey of India v. XXI, Pt 4, pp. 251-286.

Houghton, B. F. and Hackett, W. R., 1984, Strombolian and phreatomagmatic deposits of Ohakune craters, Ruapehu, New Zealand: A complex interaction between external water and rising magma. Journal of Volcanology and Geothermal Research, v. 21, pp. 207-231.

Houghton, B. F. and Schmincke, H. U., 1986, Mixed deposits of simultaneous Strombolian and phreatomagmatic volcanism: Rothenberg volcano East Eifel volcanic field. Journal of Volcanology and Geothermal Research, v. 30, pp. 117-130.

Houghton, B. F., Wilson, C. J. N. and Smith, I. E. M., 1999, Shallow-seated controls on styles of explosive basaltic volcanism: a case study from New Zealand. Journal of Volcanology and Geothermal Research, v. 91, pp. 97-120.

Landi, P., Francalancl, L., Pompilo M., Rosi, M., Corsaro, R. S., Petrone, C. M., Nardini, R. And Miraglia, L., 2006, The December 2002- July 2003 effusive event at Stromboli volcano, Italy: Insights into the shallow pumping system by petrochemical studies. Journal of Volcanology and Geothermal Research, v. 155, pp. 263-284.

Lodato L., Spampinato L., Harris A., Calvare S., Dehn J., Patrick M., 2007, The morphology and evolution of the Stromboli 2002-2003 lava flow field; an example of a basaltic flow field emplaced on a steep slope. Bulletin of Volcanology, v. 69, pp. 671-679.

Lombardo, V., Buongiorno, M. F., Peiri, D. and Meruccl, L., 2004, Differences in landsat TM derived lava flow thermal structures during summit and flank eruption at Mount Etna. Journal of Volcanology and Geothermal Research, v. 134, pp. 15-34.

Luhr, J. F. and Simkin, T. (EDS), 1993, Paricutin, the volcano born in a Mexican cornfield. Geoscience Press Inc. Phoenix 427pp

Luhr, J. F. And Haldar, D. 2006, Barren Island volcano (NE Indian Ocean): Island-arc high-alumina basalts produced by troctolite contamination. Journal of Volcanology and Geothermal Research, v.149, pp.177-212.

Macdonald, G. A., 1972, Volcanoes. Prentice-Hall Englewood Cliffs, New Jersey, 510pp.

Martin, U. and Nemeth, K., 2006, How Strombolian is a "Strombolian" scoria cone? Some irregularities in scoria cone architecture from Transmexician volcanic belt, near Volcan Ceboruco, (Mexico) and Al Haruj (Libiya). Journal of Volcanology and Geothermal Research, v. 155, pp. 104-118.

Miyabuchi, Y., Watanaba, K., and Egawa, Y., 2006, Bomb-rich basaltic pyroclastic flow deposit from Nakadake, Aso volcano, southwestern Japan. Journal of Volcanology and Geothermal Research, v. 155, pp. 90103.

Miyabuchi, Y. 2009, A 90,000-year tephrostratigraphic framework of Aso volcano, Japan. Sedimentary Geology, v.220, pp. 169-189.

Nakada, S., Nagai, M., Kaneko, T., Nozawa, A. And Suzuki-kamata, K., 2005, Chronology and products of the 2000 Miyakejima volcano, Japan. Bulletin of Volcanology, v. 67, pp. 205-218.

Pal, T., Ragav, S., Bhattacharyya, A., Bandopadhyay, P. C., Mitra, S., Renjit, M. L., Shankar, M. and Ghosh, B., 2010, The 2005-2006 eruption of the Barren volcano: evolution of basaltic magmatism in island arc setting in Andaman-Java subduction. Journal of Asian Earth Sciences, v. 43, pp. 112-123.

Pal, T., Bandopadhyay, P. C., Mitra, S. K. and Ragav, S., 2007, The 2005 eruption of Barren volcano: an explosive inner arc volcanism in the Andaman Sea. Journal Geological Society of India, v. 69, pp. 1195-1202. 
Parfitt, E. A., 2004, A discussion on the mechanisms of explosive basaltic eruptions. Journal of Volcanology and Geothermal Research, v. 134, pp. 77-107.

Patrick, M. R., Harris, A. J. L., Ripepe, M., Dehn, J., Rothery, D.A. and Calvari, S., 2007, Strombolian explosive styles and source conditions: insights from thermal FLIR video. Bulletin of volcanology, v. 69, pp. 769-784.

Raju, K. A. K., 2005, Three-phase tectonic evolution of the Andaman back arc basin. Current Science, v. 89, pp. 1932-1937.

Ray, J. S., Pandey, K., and Awasthi, N., 2013, A minium age for the active Barren Island volcano, Andaman Sea. Current Science, v. 104, No. 7, pp. 934-938.

Schmincke, H.U., 2004, Volcanism. Springer Verlag, Berlin, 324pp.

Shankar, R., Haldar, D., Absar, A. and Chakraborty, S. C., 2001, Pictorial monograph of the barren Island volcano: the lone active volcano of the Indian subcontinent. Geological Survey of India special Publication, no. 67, 87pp.

Sheth H. C., Ray, J. S., Kumar, A., Bhutani, R., Awasthi, N., 2011, Toothpaste lava from the Barren Island volcano (Andaman Sea). Journal of

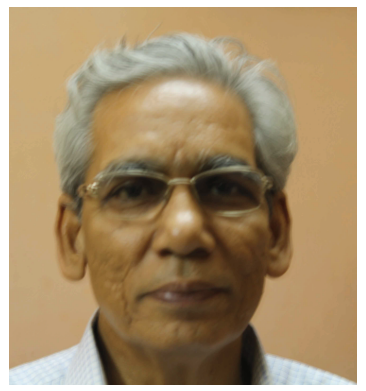

Pinaki Charan Bandopadhyay is working in the University of Calcutta as a Principal Investigator of a Book Writing Project awarded by the Department of Science \& Technology, Govt of India. Since 1981, he has served the Geological Survey of India and spent several field seasons in Andaman, Nicobar and Barren volcanic Islands and also in Proterozoic cratonic rift basins in India. His current research interests are related to sedimentology and geochemistry of the subduction zone turbidites.

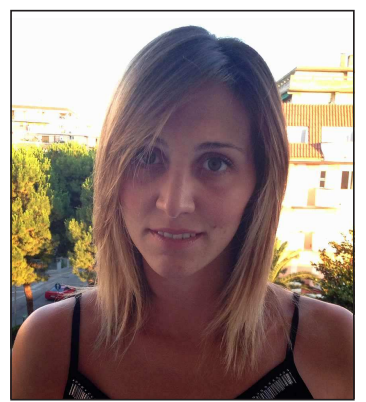

Mara Limonta is a postdoctoral fellow at the Laboratory for Provenance Studies at the University of MilanoBicocca. She works on sediments provenance, focusing on heavy mineral assemblages both in modern sediments and ancient sandstones. Her current projects involve analyses of the sediment signature of large Asian rivers (Brahamaputra, Irrawaddy, Huang He and Yangtze) and their tributaries.
Volcanology and Geothermal Research, v. 202, pp. 73-82

Sheth, H. C., Ray, J. S., Bhutani, R., Kumar, A. and Awasthi, N., 2010, The latest (2008-09) eruption of the Barren Island volcano and some thoughts on its hazards, logistics and geotourism. Current Science, v. 98 no. (5), pp. 620-627.

Sheth, H. C., Ray, J. S., Bhutani, R., Kumar, A., Smitha, R. S., 2009, Volcanology and eruptive styles of Barren Island: an active mafic stratovolcano in the Andaman Sea, NE Indian Ocean. Bulletin of Volcanologv, v. 71, pp. 9-28.

Tadducci, J. Pompilio, M. and Searlato, P., 2004, Conduit processes during the July-August 2001 explosive activity of Mt Etna (Italy): inferences from glass chemistry and crystal size distribution of ash particles. Journal of Volcanology and Geothermal Research, v.137, pp. 33-54.

Thordarson, T. and Self, S., 1993, The Laki (Skaftar-fires) and Grimsvotn eruptions in 1783-1785. Bulletin of Volcanology, v.55, no. (4), pp. 233263.

Valentine, G. A. and Gregg, T. K. P., 2008, Continental basaltic volcanoesprocesses and problems. Journal of Volcanology and Geothermal Research, v. 177, pp. 857-873.

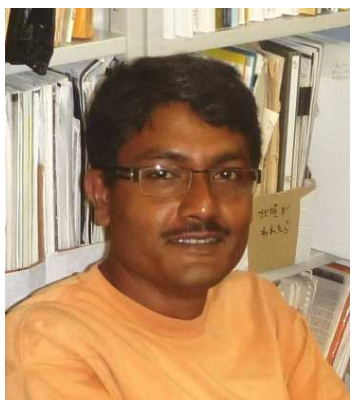

Biswajit Ghosh received his $\mathrm{PhD}$ in 2002. His research interests include ophiolites and geodynamic setting, origin of chromitites and their modifications, mantle xenoliths and symplectites. He has worked on various Phanerozoic ophiolite occurrences in Indian subcontinent. He was a geologist in Geological Survey of India and is presently working as Assistant Professor, Department of Geology, University of Calcutta, India. 